\title{
Apoplastic polyesters in Arabidopsis surface tissues - A typical suberin and a particular cutin
}

\author{
Rochus Franke ${ }^{\text {a,* }}$, Isabel Briesen ${ }^{\text {a }}$, Tobias Wojciechowski ${ }^{\text {a,1 }}$, Andrea Faust ${ }^{\mathrm{b}}$, \\ Alexander Yephremov ${ }^{\mathrm{b}}$, Christiane Nawrath ${ }^{\mathrm{c}}$, Lukas Schreiber ${ }^{\mathrm{a}}$ \\ ${ }^{\text {a } I n s t i t u t e ~ o f ~ C e l l u l a r ~ a n d ~ M o l e c u l a r ~ B o t a n y, ~ U n i v e r s i t y ~ o f ~ B o n n, ~ K i r s c h a l l e e ~ 1, ~ D-53115 ~ B o n n, ~ G e r m a n y ~}$ \\ ${ }^{b}$ Max Planck Institute for Plant Breeding Research, Carl-von-Linné-Weg 10, D-50829 Cologne, Germany \\ c Département de Biologie Moléculaire Végétale, Université de Lausanne, CH-1015 Lausanne, Switzerland
}

Received 11 May 2005; received in revised form 20 September 2005

\begin{abstract}
Cutinized and suberized cell walls form physiological important plant-environment interfaces as they act as barriers limiting water and nutrient loss and protect from radiation and invasion by pathogens. Due to the lack of protocols for the isolation and analysis of cutin and suberin in Arabidopsis, the model plant for molecular biology, mutants and transgenic plants with a defined altered cutin or suberin composition are unavailable, causing that structure and function of these apoplastic barriers are still poorly understood. Transmission electron microscopy (TEM) revealed that Arabidopsis leaf cuticle thickness ranges from only $22 \mathrm{~nm}$ in leaf blades to $45 \mathrm{~nm}$ on petioles, causing the difficulty in cuticular membrane isolation. We report the use of polysaccharide hydrolases to isolate Arabidopsis cuticular membranes, suitable for depolymerization and subsequent compositional analysis. Although cutin characteristic $\omega$ hydroxy acids (7\%) and mid-chain hydroxylated fatty acids $(8 \%)$ were detected, the discovery of $\alpha, \omega$-diacids (40\%) and 2 -hydroxy acids $(14 \%)$ as major depolymerization products reveals a so far novel monomer composition in Arabidopsis cutin, but with chemical analogy to root suberin. Histochemical and TEM analysis revealed that suberin depositions were localized to the cell walls in the endodermis of primary roots and the periderm of mature roots of Arabidopsis. Enzyme digested and solvent extracted root cell walls when subjected to suberin depolymerization conditions released $\omega$-hydroxy acids $(43 \%)$ and $\alpha$, $\omega$-diacids $(24 \%)$ as major components together with carboxylic acids $(9 \%)$, alcohols $(6 \%)$ and 2-hydroxyacids $(0.1 \%)$. This similarity to suberin of other species indicates that Arabidopsis roots can serve as a model for suberized tissue in general.
\end{abstract}

(C) 2005 Elsevier Ltd. All rights reserved.

Keywords: Arabidopsis thaliana; Brassicaceae; Apoplastic biopolymers; Cutin; Suberin; Aliphatic polyester; Very long-chain fatty acids

\section{Introduction}

As a protection mechanism from uncontrolled water loss, nutrient depletion and infection by pathogens, plants have developed specialized surface tissues covering all aerial surfaces and the subterraneous root organs. These encompassing tissues are characterized by substantial

\footnotetext{
* Corresponding author. Tel.: +49 22873 6525; fax: +49228 736811.

E-mail address: rochus.franke@uni-bonn.de (R. Franke).

${ }^{1}$ Present address: Division of Biological Sciences, University of Paisley, Paisley PA1 2BE, UK.
}

amounts of the apoplastic aliphatic biopolymers cutin and suberin, respectively.

In vascular plants the plant-atmosphere interface of all primary above-ground organs such as leaves and fruits is formed by the wax encrusted plant cuticle (Kerstiens, 1996). The cuticle is deposited at the outermost part of the epidermis cell wall as a $0.1-10 \mu \mathrm{m}$ thin membrane like layer (Vogg et al., 2004). The cuticle is composed of a lipophilic polymer matrix, the cuticular membrane, and soluble cuticular lipids, commonly known as waxes that are deposited on and encrusted in the polymer matrix (Jeffree, 1996; Kunst and Samuels, 2003). The occurrence of suberin in 
plants is highly variable. The cell walls of the periderm, the outer tissues of stems in a secondary growth stage, are known to contain the polymer suberin. In the hypodermis and endodermis, the outer and inner sealing tissues of primary roots, suberin is deposited as lamellae inside the primary cell wall close to the plasma membrane (Wilson and Peterson, 1983; Nawrath, 2002). Furthermore, suberin has been detected in the Casparian bands, endodermal cell walls of the bundle sheaths in grass leaves (Espelie and Kolattukudy, 1979) and is formed upon mechanical or pathogen caused damages to plants (Agrios, 1997).

Cutin, the matrix component of the cuticular membrane, is an insoluble biopolymer predominantly build from $\mathrm{C}_{16}$ and $\mathrm{C}_{18}$ aliphatics which are cross-linked via ester bonds, typically between carboxy and $\omega$-hydroxy groups of individual fatty acid derivatives (Deas and Holloway, 1977; Kolattukudy, 1981, 2001a). $\omega$-Hydroxyacids with additional hydroxyl and epoxy groups in secondary positions, mostly mid-chain, are the major products determined after hydrolytic depolymerization. The non-hydrolysable fraction of the cuticular membrane, named cutan (Jeffree, 1996), is poorly understood in its structure and chemical composition (Villena et al., 1999; Heredia, 2003).

Suberin is a more complex biopolymer composed of an aliphatic and an aromatic domain (Kolattukudy, 1980, 2001b; Bernards and Lewis, 1998). The latter is primarily composed of $p$-coumaric and ferulic acid, presumably involved in linking the aliphatic domain to cell wall polysaccharides (Bernards, 2002). The aliphatic domain of suberin is a polyester polymer, comprised of mainly $\omega$-hydroxyacids and $\alpha, \omega$-diacids as long-chain aliphatic constituents with chain-length ranging from $\mathrm{C}_{16}$ to $\mathrm{C}_{32}$ (Schreiber et al., 1999).

Although in-chain and $\omega$-hydroxylation activities and the subsequent oxidation of $\omega$-hydroxy groups have been demonstrated in cell free extracts (Kolattukudy, 1977, 1981), biochemical approaches to isolate enzymes directly involved in cutin or suberin biosynthesis have not succeeded yet (Kunst et al., 2004). A genetic approach to dissect cutin and suberin biosynthesis seems self-evident, however, plants with cutin-rich and suberin-rich organs such as Lycopersicon esculentum (fruit), Hedera helix (leaf) or Quercus suber (bark) that have successfully been used to study structure and physiological functions are inappropriate for molecular genetic approaches.

Recently discovered Arabidopsis mutants displaying epidermal fusion phenotypes, increased cuticular permeability or a discontinued cuticular layer in leaf sections observed by TEM, may define loci with diverse roles in cutin biosynthesis and/or deposition. The molecular characterization of the corresponding genes as fatty acid elongase (FIDDELHEAD (FDH); Pruitt et al., 2000; Yephremov et al., 1999; Efremova et al., 2004), fatty acid $\omega$-hydroxylase (LACER$A T A(L C R)$; Wellesen et al., 2001), oxidoreductase (HOTHEAD (HTH); Krolikowski et al., 2003), desaturase (WAX2; Chen et al., 2003; YRE; Kurata et al., 2003) and long-chain acyl-CoA synthase (LACS2; Schnurr et al.,
2004) suggests these genes are probably involved in the biosynthesis of functionalized aliphatics. However, a direct effect on the amount or composition of leaf cutin could not be established because methods for the analysis of Arabidopsis cutin were not available at the time. Recent progress has been made when Xiao et al. (2004) succeeded in the enzymatic isolation of Arabidopsis stem cuticles and determined cutin characteristic depolymerization products, including 16-hydroxyhexadecanoic acid, 9/10,16-dihydroxyhexadecanoic acid along with $\mathrm{C}_{16}$ and $\mathrm{C}_{18} \alpha, \omega$-diacids. Shortly after Bonaventure et al. (2004) and the work in our own laboratory, Yephremov et al. (2004) have determined unsaturated $\mathrm{C}_{18} \alpha, \omega$-diacids as the major depolymerization products of solvent extracted Arabidopsis leaves, thus providing the first indication of an unusual monomer composition of Arabidopsis leaf cutin. These findings were supported by the detection of unsaturated $\mathrm{C}_{18} \alpha, \omega$-diacids in epidermal peels of Arabidopsis stems (Bonaventure et al., 2004). However, the methods to isolate and analyze pure cuticles from Arabidopsis leafs still need to be established.

An even bigger gap exists in our knowledge about suberin biosynthesis. After extensive compositional and biochemical studies in the 1970s (Kolattukudy, 1977, 1981), research on suberin biosynthesis has mainly focused on the aromatic domain (Bernards and Lewis, 1998; Bernards and Razem, 2001), however, the function of suberin as a transport barrier for water and solutes is determined by the aliphatic domain (Hose et al., 2001; Schreiber et al., 1999). In this context, Agrawal and Kolattukudy (1978) purified a $\omega$-hydroxyacid dehydrogenase to near homogeneity from wound healing potato tuber disks, supposed to be specific for suberin biosynthesis. Details on other catalysts, and the encoding genes, involved in the biochemical pathways to aliphatic suberin are missing since reasonable forward genetic screens to isolate mutants with a phenotype consistent with a defect in suberin biosynthesis or deposition have yet to be developed. For reverse genetic approaches aimed at elucidating the function of candidate genes in the biosynthesis or deposition of aliphatic suberin monomers, methods to detect and analyze suberin in Arabidopsis are needed. In contrast to cutin were recent compositional analysis of the stem cuticle and solvent extracted leaves have been conducted successfully (Xiao et al., 2004; Bonaventure et al., 2004), no one has determined the suberin composition in Arabidopsis yet.

Here, we present the aliphatic monomer composition of isolated Arabidopsis leaf cuticles and of suberin from $\mathrm{Ara}$ bidopsis. Whereas Arabidopsis suberin consists of characteristic suberin monomers, Arabidopsis cutin is surprisingly different from what was found in other plants.

\section{Results}

\subsection{Ultrastructure of leaf cuticles of Arabidopsis}

Ultrastructural studies by transmission electron microscopy revealed that the cuticular membrane of Arabidopsis 
covers the leaf epidermis as a very fine electron opaque layer that represents only a small fraction of the outer extracellular matrix of the epidermal cell (Fig. 1A). The leaf blades of fully expanded leaves are covered with a cuticle, on average $21.8 \mathrm{~nm}( \pm 7.0 \mathrm{SD})$ in thickness that is even thinner $(17.2 \pm 4.0 \mathrm{~nm})$ in expanding leaves. An internal structure was often not clearly recognizable in these very fine cuticles. The principle cuticular membrane close to the veins tended to be slightly thicker $(30.5 \pm 6.1 \mathrm{~nm})$. This tendency is even more pronounced in petioles $(44.9 \pm 9.9 \mathrm{~nm})$ having a cuticle of up to $60 \mathrm{~nm}$. Wellpreserved cuticular membranes of these tissues have a reticulated structure (Fig. 1B) and an ultra-thin second layer covering the principle cuticular membrane. It can, however, not be totally excluded that this second layer derives from environmental factors or might be caused by osmium fixation.

\subsection{Isolation of Arabidopsis leaf cuticles}

Cuticles from many species, ranging in thickness from about 0.7 to $32 \mu \mathrm{m}$ (Schreiber and Riederer, 1996), have been isolated by incubation with cell wall hydrolyzing enzymes due to the fact that the cutin polyester resists this treatment. Subsequent solvent extraction of isolated cuticles enables the chemical analysis of the insoluble cutin polymer separately from the soluble lipid fraction, the intra- and epicuticular waxes. When the above method was applied to freshly harvested Arabidopsis leaves all plant material has been macerized using this enzyme treatment, querying whether Arabidopsis leaves are suitable for cuticle isolation at all. Given the thickness of Arabidopsis leaf cuticles of about 15-29 nm, as determined by TEM, could explain why many of our attempts to isolate this very thin and fragile cuticle from Arabidopsis using traditional methods have failed. However, when totally extracted, dried leaf discs were incubated with cellulase and pectinase and only carefully agitated, beginning after 5 days it was possible to recover very thin, translucent membranes using a binocular and a black background to contrast the floating membranes. Size and shape of the membranes were identical to that of the leaf disc starting material. In microscopic examinations of those membranes cell wall structures from epidermal cells could not be detected (Fig. 1C). Indicative
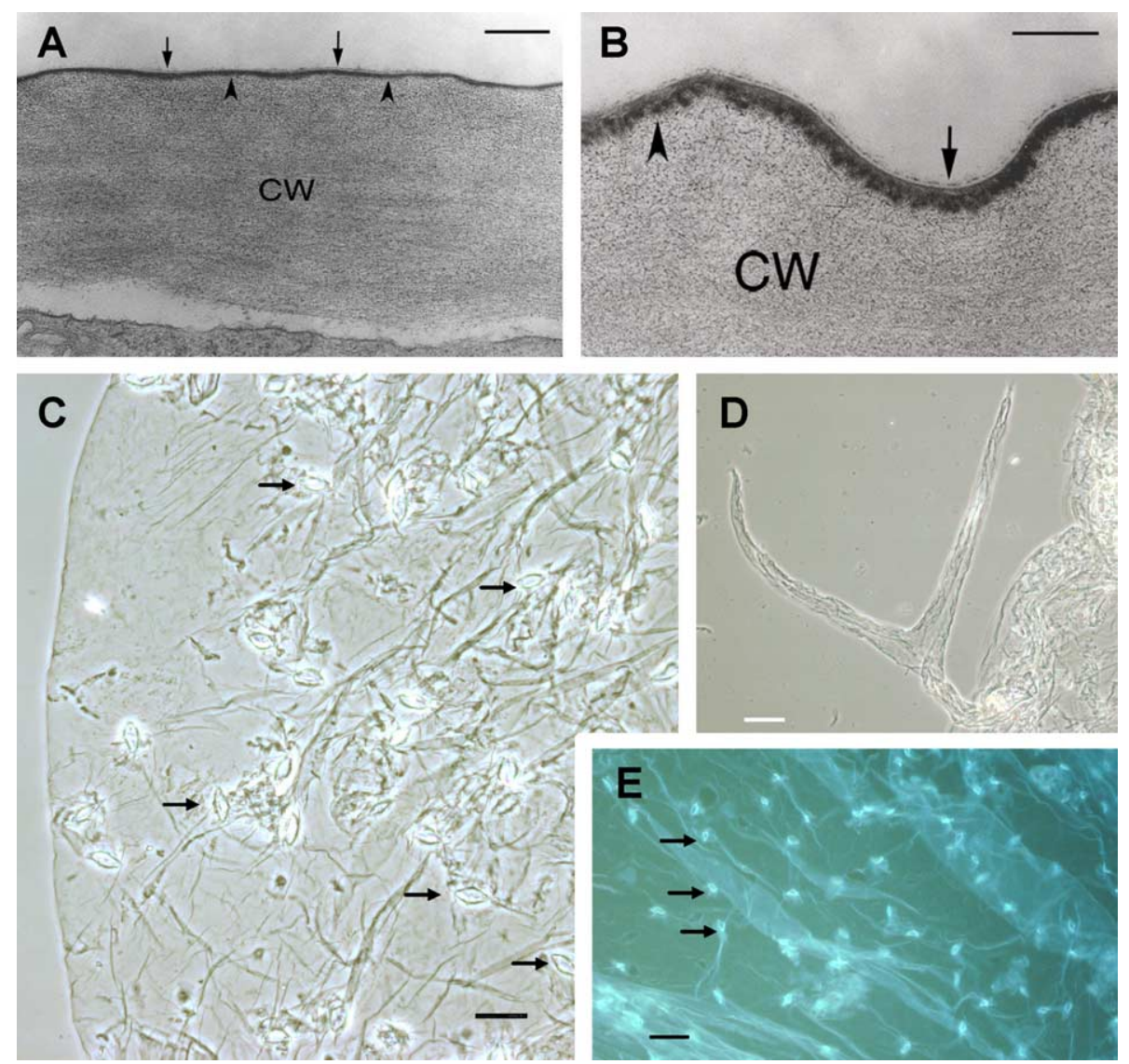

Fig. 1. Leaf cuticle ultrastructure and light microscopic analysis of membranes enzymatically removed from Arabidopsis leaf disks. (A) The extracellular matrix of outer epidermal cell walls is represented from the leaf blade and (B) close to the middle vein of a leaf. The principle cuticular membrane is indicated with black arrowheads, while an ultra-fine second layer is indicated with arrows. (C) Bright field microscopic picture in the border region of an isolated cuticular membrane. (D) Different region of (C) indicating an epidermal trichome "envelope". (E) Autofluorescence of cuticular membranes. Stomates are indicated by arrows (C and E). CW, cell wall. Scale bars are $200 \mathrm{~nm},(\mathrm{~A})$ and $(\mathrm{B}) ; 20 \mu \mathrm{m},(\mathrm{C})-(\mathrm{E})$. (For interpretation of the references to colour in this figure legend, the reader is referred to the web version of this article.) 
of cuticles, stomates can be observed because of the strongly reinforced guard cell walls. Furthermore, the trichome "envelopes" on these transparent membranes demonstrated that we successfully isolated leaf cuticles. No other cell or cell wall structures could be detected on the translucent membranes. Unlike other cuticles (Schönherr and Riederer, 1986), it was not possible to flatten the Arabidopsis cuticles without causing the wrinkly appearance of the membrane.

\subsection{Determination of ester-linked aliphatic monomers in Arabidopsis isolated cuticles}

For the chemical analysis a minimum of 30 leaf cuticles of $1 \mathrm{~cm}$ diameter were pooled per sample. After depolymerization with $\mathrm{MeOH}-\mathrm{HCl}$ the monomers were subsequently derivatized to their corresponding TMS derivatives and analyzed by GC-MS. A GC-chromatogram of the monomer mixture released from Arabidopsis cuticles is shown in Fig. 2A. As exemplified for the four most prominent peaks compounds were identified based on their EI-MS fragmentation pattern. They were readily identified as acid methyl esters from the characteristic McLafferty rearrangement ion at $\mathrm{m} / \mathrm{z}$ 74. The fragmentation pattern of compound $\mathbf{1}$ and compound $\mathbf{3}$ (data not shown) are identical to the EI mass spectra published by Holloway (1982) for methyl esters of 1,16-hexadecane dioic acid (1) and 1,18octadecene dioic acid (3), respectively. The fragmentation pattern of compound $\mathbf{2}$ (data not shown) is very similar to $\mathbf{3}$ with mass differences of two in most rearrangement ions and in the diagnostic peaks $\mathrm{m} / \mathrm{z} 274$ (276 in compound 2) and $\mathrm{m} / \mathrm{z} 306$ (308 in compound 2) indicating an additional double bound. These fragments correspond to the $\mathrm{M}^{+}-64$ and $\mathrm{M}^{+}-32$ of the predicted structure of this compound being the methyl diester of 1,18-octadecadiene dioic acid with a MW of 338, also detected in the mass spectrum. For compound 4, identified as the methylester of 2-hydroxy-tetracosanoic acid, the MS fragmentation pattern is shown in Fig. 3A. The molecular ion $\mathrm{m} / \mathrm{z} 470$ is of low abundance, the diagnostic peak at $\mathrm{m} / \mathrm{z} 455$ represents the $\mathrm{M}^{+}-15$ - loss of a methyl group from the trimethylsilyl ether moiety. The peak at $\mathrm{m} / z 411\left(\mathbf{M}^{+}-59\right)$ results from cleavage between carbon 1 and 2. Similarly more than 30 compounds were identified and quantified from the chromatogram (Table 1).

\subsection{The aliphatic monomer composition of Arabidopsis cuticles}

The methanolysate of Arabidopsis cuticles is primarily composed of saturated and unsaturated $\mathrm{C}_{16}$ and $\mathrm{C}_{18}$ hydroxylated alkanoic acids many of them known to be cutin components (Table 1). These include $\omega$-hydroxyacids, alkanoic acids, alkanols and mid-chain hydroxylated fatty acids. However, the most abundant monomers released from Arabidopsis leaf cuticles were $\alpha, \omega$-diacids, of chain length $\mathrm{C}_{16}$ and $\mathrm{C}_{18}$ and 2-hydroxyacids varying in chain

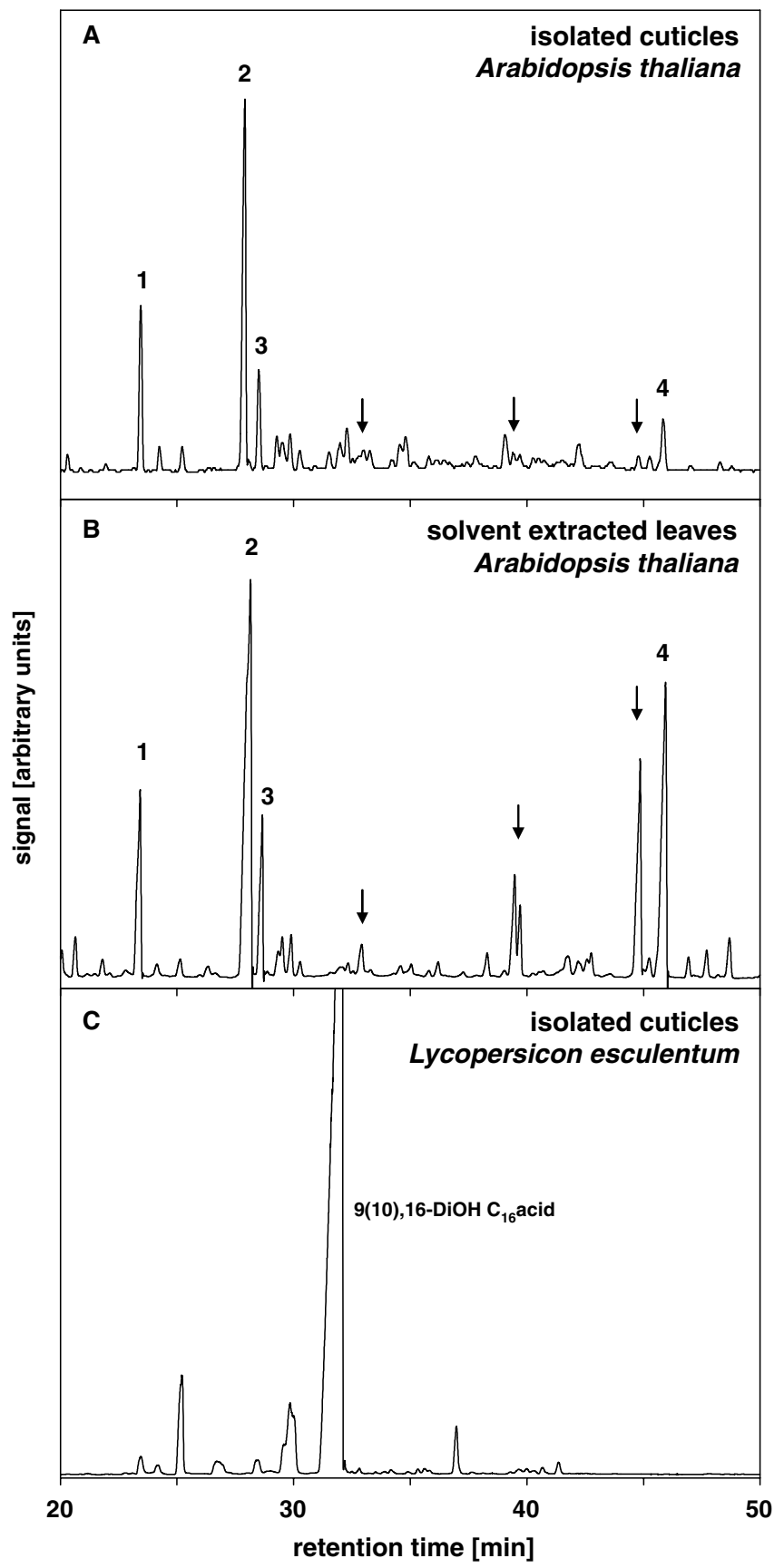

Fig. 2. Gas chromatogram of aliphatic monomers released from Arabidopsis leaf polyesters and tomato fruit cuticles by transesterification using $\mathrm{MeOH}-\mathrm{HCl}$. (A) Depolymerization products of isolated Arabidopsis cuticular membranes. (B) Depolymerization products released from totally extracted Arabidopsis leaves. (C) Depolymerization products of isolated cuticular membranes from tomato (Lycopersicon esculentum)*, representing a "standard" cutin predominantly comprised of mid-chain hydroxylated fatty acid derivatives. Monomers were extracted and derivatized to their corresponding TMS ether and ester prior to GC analysis. The predominant compounds are marked: 1 , hexadecane-1,16dioic acid**; 2, octadecadien-1,18-dioic acid**; 3, octadecene-1,18-dioic acid**; 4, 2-hydroxy-tetracosanoic acid***; 9(10),16-DiOH C16 acid, 9(10),16-Dihydroxyhexadecanoic acid***. Arrows indicate $\mathrm{C}_{20}, \mathrm{C}_{22}$ and $\mathrm{C}_{24}$ (1) 2-hydroxy acid (sorted by increasing retention time). *The detailed monomer composition of tomato cuticles has been analyzed previously (Baker and Holloway, 1970; Graça et al., 2002). **Analyzed as methyl ester. ${ }^{* * *}$ Analyzed as methylester, hydroxyl group as trimethylsilyl ether. 


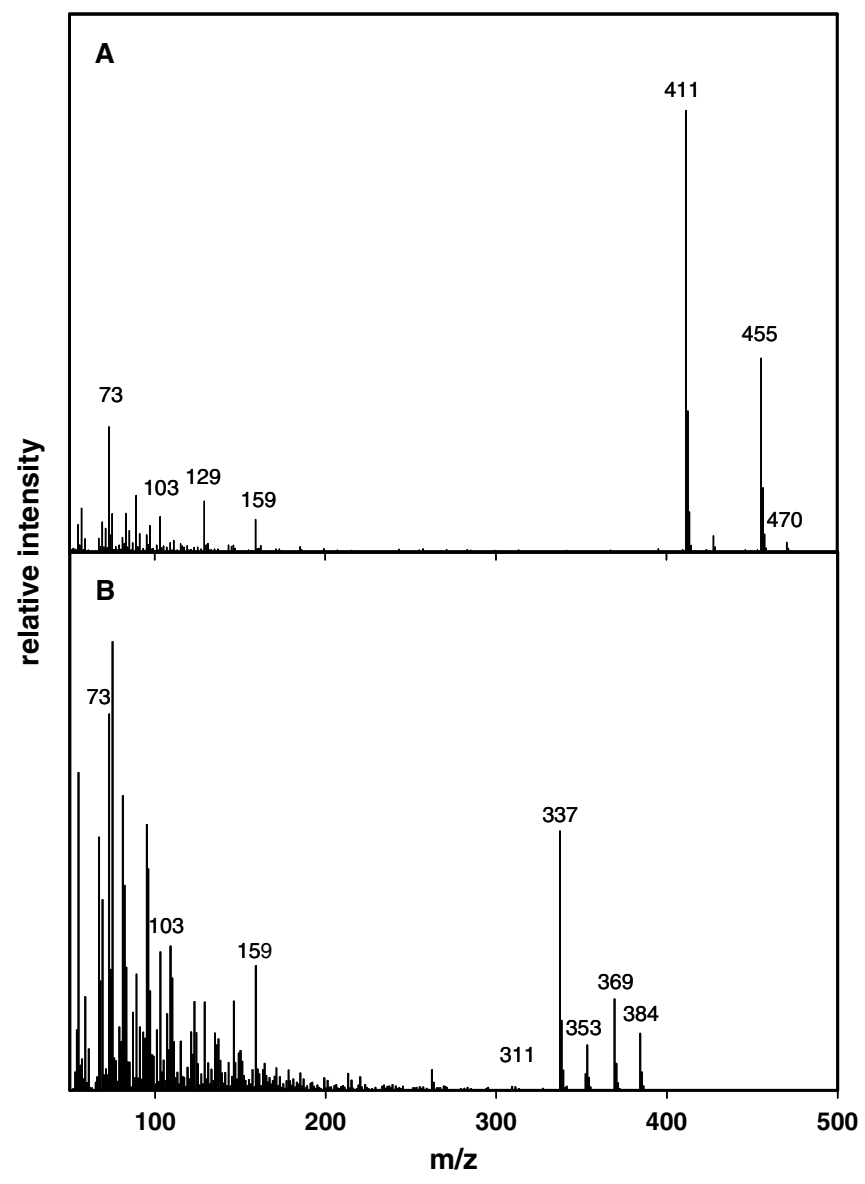

Fig. 3. EI mass spectra of transesterification products released from isolated Arabidopsis leaf cuticles (A) and hydrolase digested root cell walls (B), respectively. (A) Compound 4 in Fig. 2 identified as the methylester and TMS ether of 2-hydroxy-tetracosanoic acid. (B) Compound $\mathrm{C}_{18}(1) \omega$ in Fig. 5A identified as the methylester and TMS ether of 18-hydroxyoctadecenoic acid.

length from $\mathrm{C}_{16}$ to $\mathrm{C}_{28}$. The latter two-substance classes account for more than $50 \%$ of the monomer mixture. Of these the major component of Arabidopsis cutin is double unsaturated octadecadien-1,18-dioic acid representing $20 \%$ of the monomers released from isolated Arabidopsis leaf cuticles. Lesser, but also substantial amounts were detected of hexadecane-1,16-dioic acid (10.6\%), octadecene-1,18-dioic acid $(6.6 \%)$, 2-hydroxy-tetracosanoic acid $(4.5 \%)$, octadecane-1,18-dioic acid $(2.7 \%)$, tetracosanoic acid $(2.6 \%)$, 18hydroxy-octadecadienoic acid (2.4\%), and 2-hydroxy-hexacosanoic acid (2.3\%). All other compounds accounted for less than $2 \%$ of the monomer mixture.

Unidentified mid-chain hydroxylated fatty acids listed in Table 1 were recognized by their characteristic fragment ions $\mathrm{m} / \mathrm{z} 259$ and 273, compatible with $\mathrm{C}_{9}$ or $\mathrm{C}_{10}$ hydroxylated aliphatic acids (Holloway, 1982). Based on retention times compared to other $\mathrm{C}_{16}$ and $\mathrm{C}_{18}$ monomers they presumably include $\mathrm{C}_{18} 9(10)$-hydroxylated fatty acids. However, due to the low amounts of isolated cuticles, EI-MS fragments interfered with back ground signals hampering the determination of the exact structure. As
Table 1

Monomers released from isolated Arabidopsis leaf cuticles by methanolic$\mathrm{HCl}$ catalyzed transesterification

\begin{tabular}{|c|c|c|c|c|}
\hline \multirow[t]{2}{*}{$\begin{array}{l}\text { Cutin monomer } \\
\text { (chain length (double bonds)) }\end{array}$} & \multicolumn{2}{|c|}{$\mu \mathrm{g} / \mathrm{dm}^{2}$} & \multicolumn{2}{|c|}{$\begin{array}{l}\text { Relative } \\
\text { amounts (\%) }\end{array}$} \\
\hline & Mean & $\mathrm{SD}$ & Mean & SD \\
\hline Alkan-1-oic acids & 3.53 & 0.70 & 8.10 & 0.15 \\
\hline Hexadecanoic acid $\left(\mathrm{C}_{16}\right)$ & 0.56 & 0.02 & 1.32 & 0.23 \\
\hline Octadecanoic acid $\left(\mathrm{C}_{18}\right)$ & 0.32 & 0.12 & 0.71 & 0.12 \\
\hline Eicosanoic acid $\left(\mathrm{C}_{20}\right)$ & 0.22 & 0.05 & 0.51 & 0.13 \\
\hline Docosanoic acid $\left(\mathrm{C}_{22}\right)$ & 0.75 & 0.20 & 1.71 & 0.18 \\
\hline Tetracosanoic acid $\left(\mathrm{C}_{24}\right)$ & 1.14 & 0.43 & 2.56 & 0.47 \\
\hline Octadecenoic acid $\left(\mathrm{C}_{18}(1)\right)$ & 0.19 & 0.02 & 0.45 & 0.11 \\
\hline Octadecadienoic acid $\left(\mathrm{C}_{18}(2)\right)$ & 0.34 & 0.05 & 0.82 & 0.23 \\
\hline Alkan-1-ols & 0.68 & 0.08 & 1.57 & 0.18 \\
\hline Hexadecanol $\left(\mathrm{C}_{16}\right)$ & 0.03 & 0.00 & 0.06 & 0.01 \\
\hline Octadecanol $\left(\mathrm{C}_{18}\right)$ & 0.18 & 0.03 & 0.42 & 0.01 \\
\hline Hexacosanol $\left(\mathrm{C}_{26}\right)$ & 0.16 & 0.04 & 0.37 & 0.07 \\
\hline Octacosanol $\left(\mathrm{C}_{28}\right)$ & 0.31 & 0.01 & 0.73 & 0.12 \\
\hline$\omega$-Hydroxyacids & 3.07 & 0.70 & 7.01 & 0.27 \\
\hline 16-Hydroxy-hexadecanoic acid $\left(\mathrm{C}_{16}\right)$ & 0.68 & 0.07 & 1.59 & 0.19 \\
\hline 18-Hydroxy-octad & 0.18 & 0.03 & 0.42 & 0.06 \\
\hline 18-Hydroxy-octa & 0.09 & 0.01 & 0.20 & 0.03 \\
\hline 18-Hydroxy-octa & 1.03 & 0.24 & 2.36 & 0.15 \\
\hline 18-Hydroxy-oc & 0.81 & 0.28 & 1.83 & 0.26 \\
\hline 20-Hydroxy-eicosenoic acid $\left(\mathrm{C}_{20}(1)\right)$ & 0.27 & 0.12 & 0.60 & 0.21 \\
\hline$\alpha, \omega-1$ & 17.70 & 2.36 & 40.93 & 2.91 \\
\hline $\operatorname{acid}\left(\mathrm{C}_{16}\right)$ & 4.54 & 0.40 & 10.64 & 2.03 \\
\hline Octadecane-1,1 & 1.17 & 0.13 & 2.74 & 0.51 \\
\hline Octadecene-1,18-dioic acid $\left(\mathrm{C}_{18}(1)\right)$ & 2.83 & 0.37 & 6.58 & 1.0 \\
\hline Octadecadien-1,18-dioic acid $\left(\mathrm{C}_{18}(2)\right)$ & 9.17 & 2.02 & 20.97 & 0.6 \\
\hline 2-Hydroxyacids & 5.95 & 0.18 & 13.93 & 2.07 \\
\hline 2-Hydroxy-hexadec & 0.10 & 0.00 & 0.23 & 0.04 \\
\hline 2-Hydroxy-octadecanoic acid $\left(\mathrm{C}_{18}\right)$ & 0.14 & 0.02 & 0.33 & 0.0 \\
\hline 2-Hydroxy-eicosanoic acid $\left(\mathrm{C}_{20}\right)$ & 0.60 & 0.07 & 1.43 & 0.3 \\
\hline 2-Hydroxy-docosanoic acid $\left(\mathrm{C}_{22}\right)$ & 0.64 & 0.06 & 1.50 & 0.1 \\
\hline 2-Hydroxy-tricosanoic acid $\left(\mathrm{C}_{23}\right)$ & 0.20 & 0.06 & 0.48 & 0.1 \\
\hline 2-Hydroxy-tetracosanoic acid $\left(\mathrm{C}_{24}\right)$ & 1.93 & 0.08 & 4.52 & 0.7 \\
\hline anoic acid $\left(\mathrm{C}_{25}\right)$ & 0.18 & 0.00 & 0.42 & 0.0 \\
\hline 2-Hydroxy-hexacosano & 0.98 & 0.02 & 2.30 & 0.3 \\
\hline 2-Hydroxy-octacosanoi & 0.63 & 0.01 & 1.47 & 0.2 \\
\hline 2-Hydroxy-tetracosenoic acid $\left(\mathrm{C}_{24}(1)\right)$ & 0.55 & 0.08 & 1.26 & 0.0 \\
\hline "Mid-chain" ox & 3.77 & 0.76 & 8.64 & 0.1 \\
\hline $\begin{array}{l}\text { 9(10)-Hydroxy-hexadecane-1, } \\
\text { 16-dioic acid }\left(\mathrm{C}_{16}\right)\end{array}$ & 0.62 & 0.10 & 1.43 & 0.2 \\
\hline $\begin{array}{l}\text { 9(10),16-Dihydroxy-hexadecanoic acid } \\
\left(\mathrm{C}_{16}\right)\end{array}$ & 0.51 & 0.10 & 1.17 & 0.1 \\
\hline $\begin{array}{l}\text { Unidentified }^{\text {a }} \text { "mid-chain" } \\
\text { hydroxylated acids }\end{array}$ & 2.65 & 0.66 & 6.04 & 0.5 \\
\hline Unidentified $^{\mathrm{b}}$ longchain a & 8.87 & 3.76 & 19.82 & 4.4 \\
\hline Total & 43.57 & 8.36 & 100.0 & \\
\hline
\end{tabular}

Cuticles were isolated enzymatically from totally extracted leaf disks of 5week-old plants. Absolute amounts are given in $\mu \mathrm{g} / \mathrm{dm}^{2}$ as mean of three replicates and standard deviation (SD). Each of the three replicates includes 30 cuticular membranes of $1 \mathrm{~cm}$ diameter, pooled from 10 to 15 plants. Acids were analyzed as methyl esters, hydroxyl groups as trimethylsilyl ethers.

${ }^{a}$ Unidentified mid-chain hydroxylated fatty acids were recognized by their characteristic fragment ions $\mathrm{m} / \mathrm{z} 259$ and 273, compatible with $\mathrm{C}_{9}$ or $\mathrm{C}_{10}$ hydroxylated aliphatic acids (Holloway, 1982).

${ }^{\mathrm{b}}$ Unidentified long-chain aliphates were recognized by EI-MS spectra compatible with saturated and unsaturated long-chain fatty acid derivatives; however, exact structure determination was retarded due to low abundance of molecular weight characteristic fragment ions. 
exemplified by the methanolysate of tomato (Lycopersicon esculentum) fruit cuticles (Fig. 2C) the complex Arabidopsis cutin composition with low relative amounts of mid-chain oxygenated compounds $(8.6 \%)$ is exceptionally different to the cutin monomer composition of most other species that are mostly dominated $(50-90 \%)$ by mid-chain oxygenated $\mathrm{C}_{16}$ and $\mathrm{C}_{18}$ fatty acid derivatives (Graça et al., 2002).

\subsection{Aliphatic polyester of totally extracted leaves}

The isolated cuticles were very thin, and fragile, very frequently disintegrated or collapsed when touched with steel forceps or when transferred to different containments. Therefore, and due to the labor intensity of the cuticle isolation procedure this method is not applicable in experiments requiring high numbers of samples and multiple replicates. Furthermore, many cuticle mutants have leaf phenotypes like misshaping, organ fusions, abnormal leaf development or a patchy cuticle layer in TEM slides (Kunst et al., 2004; Yephremov and Schreiber, 2005) making cuticle isolation for chemical analysis from severe mutants or the application of this method in screening processes not practicable. In search for a more simple and feasible method we analyzed totally extracted leaves, free of soluble unbound lipids by exhaustive solvent extraction, and compared them to the isolated cuticles. As shown in Fig. 2B,the monomeric composition and the relative abundance of the compounds is very similar in isolated cuticles and solvent extracted leaves. Despite the quantitative difference in 2hydroxy acids (Fig. S1), all compounds identified in the methanolysate of isolated leaf cuticles can also be detected in the monomer mixture released by $\mathrm{MeOH}-\mathrm{HCl}$ from totally extracted leaves.

\subsection{Spatial distribution of suberized tissue in Arabidopsis roots}

The major monomers in Arabidopsis cutin, $\alpha, \omega$-diacids and 2-hydroxy acids are commonly thought to be suberin characteristic constituents (Matzke and Riederer, 1991; Schreiber et al., 1999), however, there are no compositional data on suberin in Arabidopsis in the literature. We started the characterization of Arabidopsis suberin with a histochemical investigation using exposure to long-wave UVlight to visualize aromatic domains and Sudan III, a lipophilic dye commonly used to mount aliphatic cell wall domains, to localize the suberized cell layers in Arabidopsis roots. Microscopic observation of cross-sections of freshly harvested Arabidopsis roots in their primary developmental stage (Fig. 4A) revealed a strong autofluorescence of the cell walls in the central cylinder and the endodermis when exposed to UV-light $(365 \mathrm{~nm})$. The autofluorescence is very intense in the radial endodermal cell walls indicating the presence of suberized Casparien bands. Fig. 4B shows that the Sudan III staining resulted in an intensive red color only of endodermis cell walls, indicating the presence of aliphatic suberin in these cells. Intensive staining in radial walls and inner tangential walls close to the endodermispericycel boundary are indicative for a stronger suberin depositions typical for an endodermis in a secondary developmental stage (Schreiber et al., 1999). The autofluorescence in the Sudan III negative central cylinder is most likely caused by lignin phenolics. When root sections of a secondary developmental stage were observed under UVlight again an autofluorescence from lignin aromatics was detectable in the central cylinder (Fig. 4C). Different to roots in the primary developmental stage a fluorescing endodermis was no longer detectable, but a strong autofluorescence could be observed in the periderm, an outer border tissue resulting from secondary thickening. Staining with Sudan III resulted in an intense red colorization of the peridermal cell walls, indicating significant suberization of the peridermal cell walls (Fig. 4D).

Investigating the ultrastructure of the sudan-staining tissues using TEM confirmed the deposition of suberin in the casparian bands of the endodermis of primary roots (data not shown) and suberization of the whole endodermal cells as well as peridermal cells during secondary root growth (Fig. 4E). In all cases, suberin was recognized by its typical lamellae structure (Bernards and Lewis, 1998; Schmutz et al., 1996) of alternating electron-opaque and electrontranslucent layers when the tissue was cut perpendicularly to the suberin layers (Fig. 4F).

\subsection{Isolation of a suberized cell wall fraction from Arabidopsis roots}

The chemical composition of root suberin from different species has been determined from enzymatically isolated, suberin enriched endodermal or rhizodermal cell walls (Schreiber et al., 1999). Due to the branching and small size of Arabidopsis roots, isolation and purification of suberized endodermal or peridermal cell walls for detailed suberin analysis would be, if feasible, very labor intensive. We therefore used a treatment with polysaccharide hydrolases to reduce the back ground of nonsuberized tissue in the chemical analysis of whole root cell walls. A gravimetric determination revealed that $62.98 \%( \pm 1.42 \mathrm{SD})$ of the polymeric cell wall material was removed by this treatment. After incubation of Arabidopsis roots with cellulase and pectinase cortex cells are no longer detectable. In addition to the lignified cells in the central cylinder, only the Sudan III positive cell layers from the periderm remains, indicating that most of the presumably polysaccharide dominated unmodified parenchyma cell walls were removed (data not shown). Since lignin monomers do not interfere with the chemical analysis of the long-chain aliphatic components of suberin, this prepurified cell wall fraction was used for the chemical analysis of the monomer composition of aliphatic suberin.

\subsection{Aliphatic suberin monomer composition}

The GC-MS analysis of the TMS-derivatized monomers in the methanolysate revealed a complex monomer 

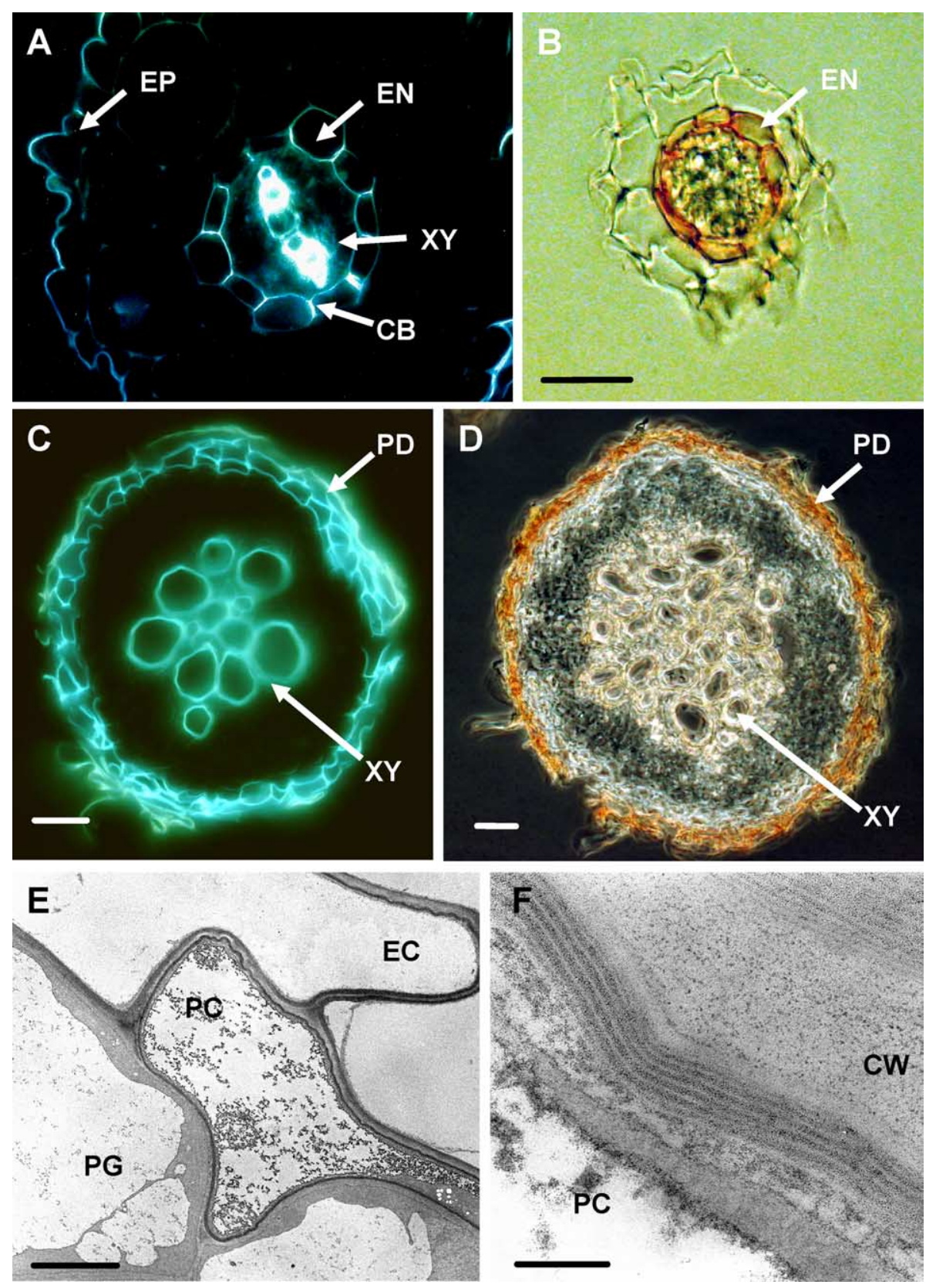

Fig. 4. Histochemical and TEM examination of Arabidopsis roots. For light microscopy (A-D) $20 \mu \mathrm{m}$ cross-sections were taken from root bundles of 5week-old plants to obtain multiple developmental stages. (A) Autofluorescence in a cross-section of a primary root after excitation with UV-light $(\lambda=365 \mathrm{~nm})$. Casparian bands (CB) are indicated by arrows. (B) Bright field microscopic picture of a primary root section after staining with the lipophilic dye Sudan III. Suberin, stained with Sudan III (red), is deposited in the endodermal cell walls. (C) Autofluorescence micrograph of a mature root section where secondary growth has occurred. Strong autofluorescence in the peridermal cell walls indicates aromatic domains. (D) Sudan III stained suberin in the periderm of a mature root section. Bars $=20 \mu \mathrm{m}(\mathrm{A}-\mathrm{D})$. (E-F) Ultrastructure of suberized root tissues of Arabidopsis plants at the beginning of the secondary thickening of the root. (E) Overview of suberized endodermal and peridermal cells in the root. The fully suberized peridermal cells typically collapse during the dehydration and embedding procedures necessary for TEM because of the low permeability of the suberized cell walls. Bar $=1 \mu \mathrm{m}$. (F) Fine structure of suberin. The structure of the lamellae with an alternation of electron-opaque and electron-translucent layers of suberin is clearly visible when the specimen is cut perpendicularly to the suberin layers. Bar $=100 \mathrm{~nm}$. EP, epidermis; EN, endodermis; PD, periderm; XY, xylem; $\mathrm{CB}$, Casparian band; EC, endodermal cell; PC, peridermal cell; PG, phellogen; CW, cell wall. (For interpretation of the references to colour in this figure legend, the reader is referred to the web version of this article.)

composition of the hydrolase resistant Arabidopsis root cell wall fraction. Twenty-four compounds detected in the GC chromatogram (Fig. 5A) were identified based on their EImass spectra. The most prominent peak $\left(\mathrm{C}_{18}(1) \omega\right.$ in Fig. 5) was identified as the methylester of the trimethylsilated 18- hydroxy-octadecenoic acid (Fig. 3B). The $m / z 384$ peak represents the mol-ion of the predicted molecule structure. The peak at $\mathrm{m} / z 103$ is diagnostic for the loss of $\mathrm{CH}_{2} \mathrm{O}$ $\mathrm{Si}\left(\mathrm{CH}_{3}\right)_{3}$ from the TMS-derivatized $\omega$-hydroxy group. The $m / z$ 369, 353 and 337 represent the $\mathrm{M}^{+}-15$ (loss of 


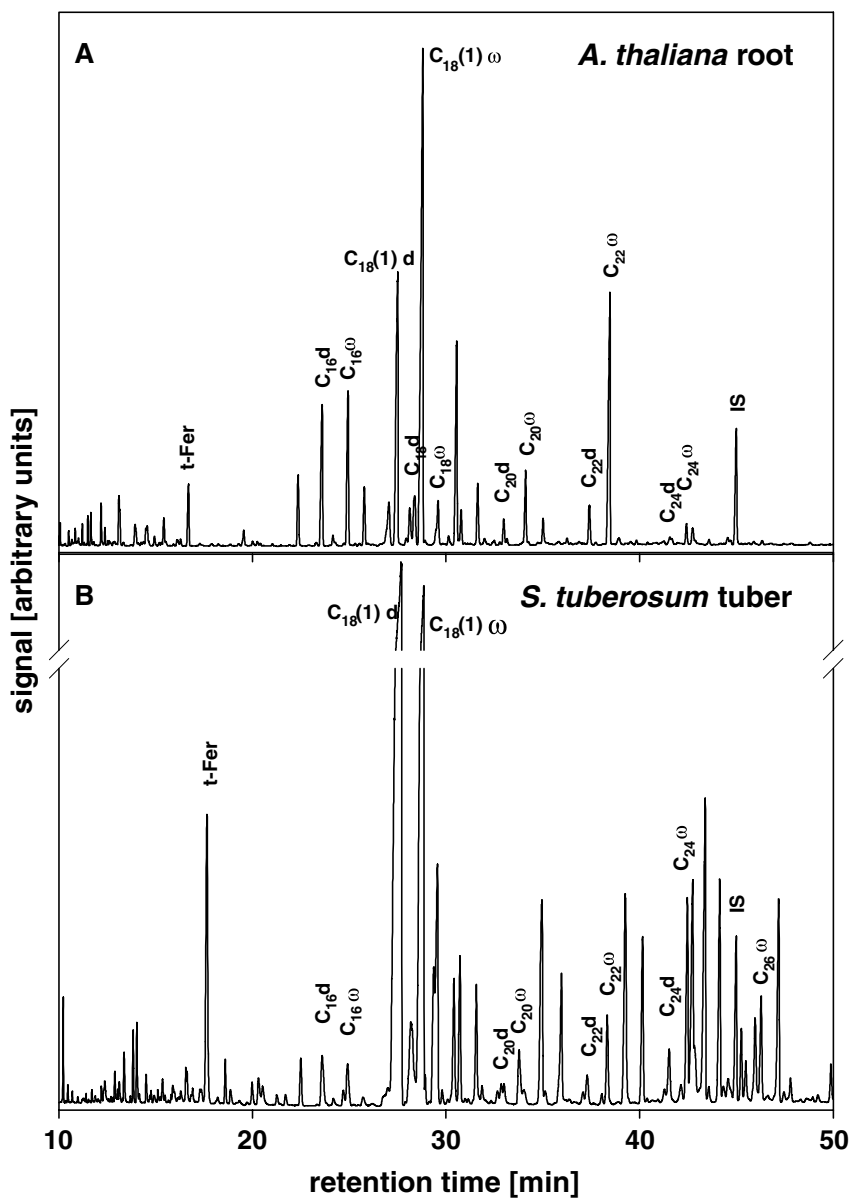

Fig. 5. Gas chromatogram of suberin monomers obtained after $\mathrm{BF}_{3} /$ $\mathrm{MeOH}$ depolymerization of hydrolase digested Arabidopsis root cell walls (A) and potato (Solanum tuberosum) tuber periderm (B). The depolymerization products were extracted and TMS derivatized before GC separation. The two most prominent suberin monomers 18-hydroxyoctadecenoic acid and octadecene-1,18-dioic acid are labeled as $\mathrm{C}_{18}(1) \omega$ and $\mathrm{C}_{18}(1) \mathrm{d}$, respectively. To exemplify the chain-length distribution in Arabidopsis, ranging from $\mathrm{C}_{16}$ to $\mathrm{C}_{24}$, the homologous series of $\alpha, \omega$-diacids is marked with $\mathrm{d}$ and the homologous series of $\omega$-hydroxy-acids is marked with $\omega$.

methyl group), $\mathrm{M}^{+}-31$ (loss of methoxy group) and $\mathrm{M}^{+}-47\left(\mathrm{CH}_{3}-\mathrm{O}_{2}\right)$, respectively.

All carboxylic groups in the methanolysate are methylated, indicating that they were formerly esterified in the polymer. GC-MS identification of the other compounds revealed that the root suberin-enriched cell wall fraction predominantly comprised saturated and monounsaturated $\omega$-hydroxy acids (43\%) and $\alpha, \omega$-dicarboxylic acids $(24 \%)$, but also carboxylic acids $(10 \%)$, alcohols $(6 \%)$ and 2 hydroxyacids $(<1 \%)$ (Table 2). Aromatic constituents $(5 \%)$ detected were the cis and trans isomers of ferulic acid and $p$-coumaric acid. This substance class composition is very similar to the suberin composition of other species (Fig. 5B; Schreiber et al., 1999, 2005a). Similar to potato tuber periderm, the two most abundant monomers released from hydrolase digested and solvent extracted root cell wall fractions, are the monounsaturated $\mathrm{C}_{18} \omega$-hydroxy acid $(23 \%)$ and $\alpha, \omega$-diacid (11\%). The chain length distribution
Table 2

Monomers released from hydrolase resistant Arabidopsis root cell walls by $\mathrm{BF}_{3} / \mathrm{MeOH}$ transesterification

\begin{tabular}{|c|c|c|c|c|}
\hline \multirow[t]{2}{*}{$\begin{array}{l}\text { Suberin monomer (chain length } \\
\text { (double bonds)) }\end{array}$} & \multicolumn{2}{|l|}{$\mu \mathrm{g} / \mathrm{mg}$} & \multicolumn{2}{|c|}{$\begin{array}{l}\text { Relative } \\
\text { amounts (\%) }\end{array}$} \\
\hline & Mean & SD & Mean & SD \\
\hline Alkan-1-oic acids & 6.27 & 1.19 & 9.64 & 0.7 \\
\hline Octadecanoic acid $\left(\mathrm{C}_{18}\right)$ & 0.08 & 0.03 & 0.12 & 0.03 \\
\hline Eicosanoic acid $\left(\mathrm{C}_{20}\right)$ & 1.43 & 0.66 & 2.23 & 0.8 \\
\hline Docosanoic acid $\left(\mathrm{C}_{22}\right)$ & 3.82 & 0.83 & 6.18 & 0.7 \\
\hline Tetracosanoic acid $\left(\mathrm{C}_{24}\right)$ & 0.94 & 0.82 & 1.11 & 0.5 \\
\hline Alkan-1-ols & 4.06 & 1.39 & 6.43 & 1.0 \\
\hline Octadecanol $\left(\mathrm{C}_{18}\right)$ & 1.39 & 1.08 & 2.11 & 1. \\
\hline Eicosanol $\left(\mathrm{C}_{20}\right)$ & 1.56 & 0.41 & 2.49 & 0.1 \\
\hline Docosanol $\left(\mathrm{C}_{22}\right)$ & 1.12 & 0.31 & 1.83 & \\
\hline$\omega$-Hydroxyacids & 27.10 & 7.73 & 43.19 & 4.1 \\
\hline 16-Hydroxy-hexadecanoic acid $\left(\mathrm{C}_{16}\right)$ & 3.63 & 1.26 & 5.77 & 1.2 \\
\hline 18-Hydroxy-octadecanoic acid $\left(\mathrm{C}_{18}\right)$ & 1.55 & 0.47 & 2.73 & \\
\hline 20 -Hydroxy-eicosanoic acid $\left(C_{20}\right)$ & 1.93 & 0.60 & 3.07 & \\
\hline 22-Hydroxy-docosanoic acid $\left(\mathrm{C}_{22}\right)$ & 4.82 & 1.06 & 7.79 & \\
\hline 24-Hydroxy-tetracosanoic acid $\left(\mathrm{C}_{24}\right)$ & 0.76 & 1.09 & 0.71 & \\
\hline 18-Hydroxy-octadecenoic acid $\left(\mathrm{C}_{18}(1)\right)$ & 14.40 & 3.77 & 23.11 & 2.2 \\
\hline$\alpha, \omega$-Dicarboxylic acids & 15.53 & 6.26 & 24.21 & \\
\hline Hexadecane-1,16-dioic acid $\left(\mathrm{C}_{16}\right)$ & 3.12 & 1.24 & 4.91 & \\
\hline Octadecane-1,18-dioic acid $\left(\mathrm{C}_{18}\right)$ & 4.05 & 3.92 & 5.87 & \\
\hline Eicosane-1,20-dioic acid $\left(\mathrm{C}_{20}\right)$ & 0.65 & 0.25 & 1.01 & 0.2 \\
\hline Docosane-1,22-dioic acid $\left(\mathrm{C}_{22}\right)$ & 0.86 & 0.21 & 1.39 & \\
\hline Tetracosane-1,24-dioic acid $\left(\mathrm{C}_{24}\right)$ & 0.24 & 0.20 & 0.35 & \\
\hline Octadecene-1,18-dioic acid $\left(\mathrm{C}_{18}(1)\right)$ & 6.62 & 1.50 & 10.68 & \\
\hline 2-Hydroxyacids & 0.08 & 0.07 & 0.12 & 0.1 \\
\hline 2-Hydroxy-tetracosanoic acid $\left(\mathrm{C}_{24}\right)$ & 0.08 & 0.07 & 0.12 & \\
\hline Hydroxycinnamic acids & 3.11 & 1.84 & 5.15 & 3.5 \\
\hline$c i s-p$-Coumaric acid & 0.22 & 0.16 & 0.38 & 0. \\
\hline trans-p-Coumaric acid & 0.71 & 0.29 & 1.13 & 0.3 \\
\hline cis-Ferulic acid & 0.95 & 1.14 & 1.64 & 2.24 \\
\hline trans-Ferulic acid & 1.23 & 0.52 & 2.01 & 0.9 \\
\hline Unidentified $^{\mathrm{a}}$ longchain aliphates & 6.55 & 3.21 & 11.26 & 3. \\
\hline Total & 62.71 & 16.02 & 100.0 & \\
\hline
\end{tabular}

Root cell walls were prepared from 5-week-old plants. Amounts are given as $\mu \mathrm{g}$ suberin per $\mathrm{mg}$ cell wall. Mean and SD was determined from 10 replicates each representing the roots of 5-7 plants. Acids were analyzed as methyl esters, hydroxyl groups as trimethylsilyl ethers.

a See unidentified long-chain aliphates in footnote b of Table 1.

within most substance classes ranges from $\mathrm{C}_{16}$ to $\mathrm{C}_{24}$ with $\mathrm{C}_{18}$ being the most prominent members (Fig. 6). Different to cutin a second peak with compounds of 22 carbon units exists among the suberin substance classes.

\section{Discussion}

\subsection{Cuticles can be isolated from Arabidopsis leaves}

Leaf cuticles have been isolated from many plant species and used in physiological transport studies or for detailed chemical analysis (Schreiber and Riederer, 1996; Kolattukudy, 2001a). However, the investigated species are neither good biochemical nor molecular genetic model systems leaving a great gap in our knowledge about cutin 


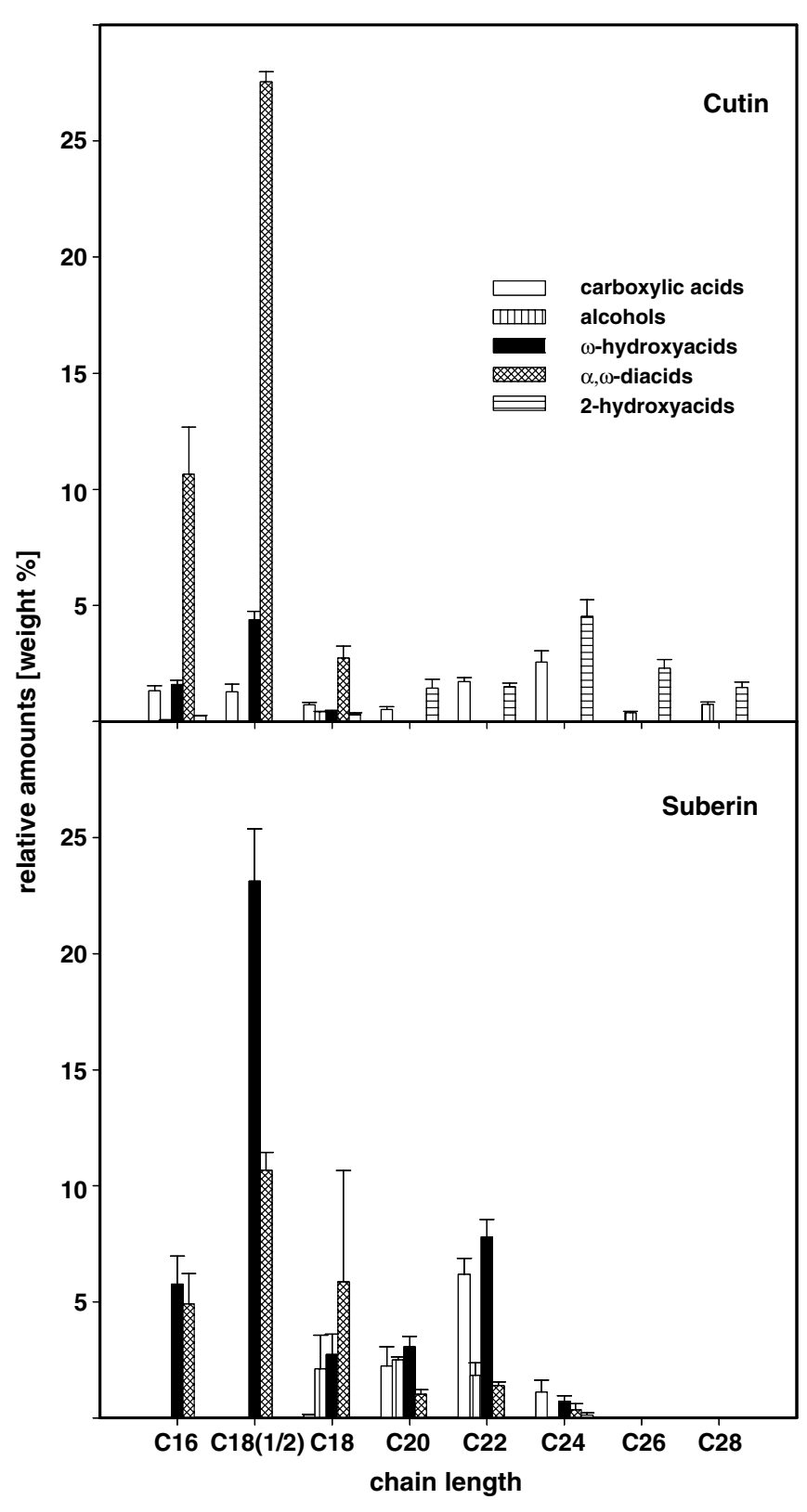

Fig. 6. Chain length distribution of aliphatic monomers released by transesterification from Arabidopsis cutin and suberin, respectively.

biosynthesis and deposition, its regulation and structurefunction relationships. On the other hand, genetic approaches have led to the discovery of many putative cutin mutants in Arabidopsis, but for most of the mutated genes a role in cuticle biosynthesis or deposition is assumed based on database annotation only (Yephremov and Schreiber, 2005). A direct involvement of these genes in cutin biosynthesis could not be demonstrated because methods for the isolation and chemical analysis of very thin cuticles, like in Arabidopsis, have not been established yet.

As indicated by the presence of stomates and trichomes, the lack of cell walls and the transparency of the enzymatically isolated membranes from Arabidopsis leaves (Fig. 1), we succeeded in the isolation of cuticular membranes suit- able for depolymerization and subsequent compositional analysis. Although the light-microscopic investigation cannot finally exclude associated cell wall or plasma membrane contaminants, Table 1 shows that $\mathrm{C}_{16}$ and $\mathrm{C}_{18}$ carboxylic acids, typical for membrane phospholipids are very minor components in the methanolysate. Similarly, membrane characteristic sterols such as $\beta$-sitosterol (Schaeffer et al., 2001) were only detected in traces and cell wall carbohydrate characteristic pyranose and furanose peaks were not detectable in the methanolysate of isolated cuticles.

\subsection{The thickness of the Arabidopsis cutin layer is in the nanometer range}

The methanolysis of isolated Arabidopsis cuticles yielded in $0.44 \mu \mathrm{g}$ aliphatic monomers per $\mathrm{cm}^{2}$ (Table 1). Based on an average cuticle density of $0.94 \times 10^{-3} \mathrm{~kg} \mathrm{~m}^{-3}$ (Schreiber and Schönherr, 1990), the total cutin monomers correspond to a leaf cuticular membrane of $4.1 \mathrm{~nm}$ compared to $15-29 \mathrm{~nm}$ as determined by TEM on leaf blades. This might indicate a so far undiscovered structural organization below TEM resolution in cuticles of leaf blades but detectable in regions of thicker cuticles. The well-preserved cuticle membrane of the veins and petioles have a reticulate structure, similar as seen in stems of Arabidopsis analyzed by Chen et al. (2003). A less electron-opaque outer layer has not been observed in our studies. However, a second ultra-thin electron-dense layer was regularly observed in samples evidencing well-preserved internal structure of the cuticular membrane.

With regard to the potential deficit of the cuticle thickness determined by analytical chemistry, a none-hydrolysable cutan fraction was reported for Arabidopsis stem cuticles (Xiao et al., 2004), but was not detectable in our analysis of leaf cuticles. Furthermore, osmium tetroxide stained lipid membranes in TEM pictures are not necessarily pure lipid fractions and our quantification is based on the internal standard dotriacontane since standards for most cutin monomers are not available. Therefore, monomer-specific response factors, which have been reported to be higher for $\omega$-hydroxyacids and $\alpha, \omega$-diacids (Graça and Pereira, 2000a) could not be applied.

\subsection{The Arabidopsis cutin is unusually rich in $\alpha, \omega-$ dicarboxylic acids}

Arabidopsis leaves are covered by a mixed $\mathrm{C}_{16}$ and $\mathrm{C}_{18}$ type cuticle (Fig. 6) according to the chain length based classification by Holloway (1982). Compared to "control" samples for cutin characteristic mid-chain hydroxy fatty acids (Lycopersicon esculentum cuticles, Fig. 2C), epoxides (Prunus avium cuticles, data not shown) and $\omega$-oxo-acids (16-oxo-hexadecanoic acid standard), epoxides or aldehydes ( $\omega$-oxo-acids) could not be detected in the methanolysate of Arabidopsis cuticles. Although $\mathrm{C}_{16}$ and other mid-chain hydroxylated fatty acids, are present in significant amounts, Table 1 and Fig. 2 show that the 
Arabidopsis cutin methanolysate is mostly comprised of $\alpha, \omega$-dicarboxylic acids, monomers that have only been reported as very minor leaf cutin components in Brassica oleracea and Spinacia oleracea (Holloway, 1982). Recently, Bonaventure et al. (2004) indicated very nicely that $\alpha, \omega-$ diacids might be considerable leaf cutin components by a similar distribution of depolymerization products, particularly $\alpha, \omega$-diacids, obtained from Arabidopsis extracted leaves and mechanically isolated stem epidermal peels. In agreement with their analysis of leaf polyester, our analysis of isolated cuticles demonstrated that saturated and unsaturated $\mathrm{C}_{16}$ and $\mathrm{C}_{18}$ dicarboxylic acids contribute to more than $40 \%$ of the cutin monomers, indicating that $\alpha, \omega$-diacids are major structural components in leaf cuticles of $\mathrm{Ara}$ bidopsis. Consistent with an important role of $\alpha, \omega$-diacids, in cutin cross-linking and proper cuticle structure in $\mathrm{Ara}$ bidopsis, lcr and att1, mutants in P450-genes encoding fatty acid $\omega$-hydroxylases presumably involved in the pathway to $\alpha, \omega$-diacids, show patchy or thicker cuticular membranes in TEM observations (Wellesen et al., 2001; Xiao et al., 2004). In the cutin polymer $\alpha, \omega$-diacids could function as ester-linker between hydroxyl groups in the cutin polymer and hydroxyl groups in other cell wall polymers such as carbohydrates.

The high amounts of $\alpha, \omega$-diacids and low amounts of mid-chain hydroxyl groups could cause fewer cross-links via secondary hydroxyls and might lead to parallel aligning structures resulting in a polymer assembly of high density, allowing Arabidopsis to live with a very thin cuticle compared to other species. Similar structure models have been proposed for the aliphatic domain of suberin, that is also characterized by substantial amounts of diacids and a moderate content of secondary functional groups (Kolattukudy, 2001b; Bernards, 2002). This unusual, rather suberin-like $\alpha, \omega$-diacid content in the cutin might be unique to Arabidopsis, but could also bee a biochemical property of very thin cuticular membranes. However, cuticles below $50 \mathrm{~nm}$ thickness have not been isolated and analyzed before.

Although response factors to determine molecular ratios are not available, the high amounts of $\alpha, \omega$-diacids implicates an excess of carboxyl groups, indicated by an carboxyl:hydroxyl ratio of $3.8: 1$, based on the quantification results. The triol glycerol, that has only recently been identified as a cutin component (Graça et al., 2002), has been proposed to replace the role of $\omega$-hydroxylgroups in ester-linkages. Glycerol $\left(0.0015 \mu \mathrm{g} / \mathrm{cm}^{2}\right)$ could be detected in the Arabidopsis cuticle methanolysate, however, hydrophylic compounds like glycerol are rather discriminated by the applied protocol; therefore the glycerol determination is not quantitative.

\subsection{Long-chain 2-hydroxy fatty acids are exceptional cutin components in Arabidopsis}

Even though polymer-bound 2-hydroxy acids have been described as constituents (2-12\%) of leaf polyester (Matzke and Riederer, 1990, 1991), this compounds have frequently been reported as monomers of suberin (Schreiber et al., 1999), most prominent, with up to $28 \%$, in suberin of endodermal cell walls in roots (Zeier et al., 1999b). The higher amounts of 2-hydroxy acids in extracted leaves compared to isolated cuticles (Figs. 2 and S1), gives raise to the question whether they are cutin components only or if they are also components of other apoplastic polymers co-isolated with the cuticular membranes. Structurally, the major 2-hydroxy acid, 2-hydroxy-tetracosanoic acid, is identical to the acyl chain of ceramide derived membrane sphingolipids (Lynch and Dunn, 2004). As stated above the enzymatically isolated cuticles, exhaustively extracted with chloroform-methanol, are almost free of membrane contaminants, indicating that 2-hydroxy acids are true cutin components in Arabidopsis, with so far unknown function. This amphiphatic molecules could act as cutin primers anchored in the plasma membrane with their hydrophobic tail, providing polymerization sites by their bifunctional hydrophilic head of carboxyl and hydroxyl substituents; for example in the anticlinal epidermis cell walls where the cuticle proper and the plasma membrane are close together. Because such a fine structural element might get disrupted during incubation with hydrolases the 2-hydroxy acid content in cuticles is lower compared to extracted leaves. 2-Hydroxy acids could also function as hydrophobic end caps esterified to other cutin monomers. Despite the difference in the distribution of 2-hydroxyacids, qualitatively the monomer composition of isolated cuticles and solvent extracted leaves were identical (Figs. 2 and S1), demonstrating that for compositional analysis, leaf tissue exempt from soluble lipids by organic solvents can be employed as cuticle equivalent.

\subsection{Endodermis and peridermis are suberized tissues in Arabidopsis roots}

Because the major cutin monomers in Arabidopsis have been described in the literature as characteristic suberin constituents (Kolattukudy, 1981; Matzke and Riederer, 1991; Zeier et al., 1999a; Schreiber et al., 1999), a second aim of this study was to investigate the occurrence and chemical composition of suberin in Arabidopsis. Histochemical staining with Sudan III and TEM observations indicated that in Arabidopsis roots suberin is deposited in the cell wall of the endodermis of younger root sections and the peridermal cells at the beginning of secondary growth and in the periderm of fully developed roots, respectively. These findings suggest profound changes in tissue specific suberin deposition during root maturation and could reflect a dual role of suberin during root development. In young roots, suberin depositions function as an inner barrier guarding the central cylinder from significant water and nutrient losses, supported by stronger suberin depositions on inner tangential and radial walls in the endodermis (Fig. 4B). In mature roots, suberin builds an outer barrier protecting the organ from pathogens in the rhizophere, incorporation of toxic solutes and strengthens the cell wall and the whole root organ. 
3.6. The monomer composition of hydrolase resistant Arabidopsis root cell walls represents a typical suberized plant tissue

Suberin monomers equivalent to $6.3 \%$ of the enzyme resistant cell wall fraction were released by transesterification. Similar amounts have been determined in enzymatically isolated endodermal cell walls of monocotyledonous species (Zeier and Schreiber, 1998; Zeier et al., 1999b). Compared to dicotyledonous plants this is lower than the $9.8 \%$ of Ricinus communis L. and $19.5 \%$ of Cicer arietinum root endodermal cell walls (Zeier et al., 1999a) probably due to the fact that our starting material also contained the lignified cell walls of the xylem. These comparisons, complicated by the fact that different cell wall fractions have been isolated from different species, points out that comparisons of suberin amounts referring to the dry weight of the isolated cell wall material is not accurate. Based on the function of suberin as an apoplastic barrier, Schreiber et al. (2005b) suggested to relate the suberin amount to surface area for comparison of different species. In our experiments, $1 \mathrm{mg}$ isolated root cell wall material correlated to $1.18 \mathrm{~cm}^{2}$ root surface resulting in $50.5 \mu \mathrm{g}$ aliphatic suberin per $\mathrm{cm}^{2}$, similar to species with a multilayered hypodermis or a root periderm (Schreiber et al., 2005a). Although this surface amount is representative due to the analysis of mature roots predominantly suberized in the periderm (Fig. 4D), methods to isolate endodermal cell walls representing an inner suberized surface needs to be established for actual tissue specific surface amounts.

The substance class composition with high relative amounts of $\omega$-hydroxyacids and $\alpha, \omega$-diacids and a high proportion of $\mathrm{C}_{18}$ unsaturated aliphatics is in good agreement with the composition of lamella suberin from other dicotyledonous and monocotyledonous species (Fig. 5; Zeier et al., 1999a; Zeier and Schreiber, 1998; Schreiber et al., 2005a). Furthermore, the $C_{16}$ and $C_{18}$ aliphatics were the major suberin monomers, which showed an overall chain length distribution ranging from $\mathrm{C}_{16}$ to $\mathrm{C}_{24}$ (Fig. 6). Similar to the analysis of $Q$. suber and Pseudotsuga menziesii suberin, glycerol $\left(0.025-0.079 \mu \mathrm{g} \mathrm{mg}^{-1}\right)$ could also be detected in the methanolysate of the enzyme resistant cell wall fraction, indicating polymer-bound glycerol. This is consistent with the recently proposed structure models of the suberin polyester containing glycerol as a "linker" between carboxylated suberin monomers (Graça and Pereira, 2000b; Bernards, 2002). Thus, there are no significant quantitative and qualitative differences in the aliphatic monomer composition of Arabidopsis root cell walls and suberin of other dicotyledonous and monocotyledonous species. Therefore, Arabidopsis root cell walls can serve as a good model for suberized plant tissues in general.

\subsection{Similar monomers in Arabidopsis cutin and suberin}

In the direct comparison of the aliphatic monomer composition Arabidopsis cutin and suberin is strikingly similar.
Only minor differences can be detected concerning chainlength distribution, saturation of $\mathrm{C}_{18}$ monomers and dominance of substance classes (Fig. 6). In addition to the maximum of $\mathrm{C}_{18}$ aliphatics, the chain-length distribution of suberin is characterized by a second maximum of very long-chain molecules with carbon chain length of 22 whereas in cutin only carboxylic acids and 2-hydroxyacids are elongated beyond $\mathrm{C}_{18}$. In suberin the major $\mathrm{C}_{18}$ monomers are monounsaturated $\omega$-hydroxy acids, whereas in cutin double unsaturated $\alpha, \omega$-diacids are the major $\mathrm{C}_{18}$ derivatives. Despite this differences in the relative amounts of individual aliphatic monomers Arabidopsis cutin and suberin comprised the same substance classes suggesting that the biosynthesis of aliphatic cutin and suberin monomers in Arabidopsis requires similar enzyme activities and presumably share common pathways. This is supported by the fact that $H T H, L C R, K C S 1$ and LACS2 genes presumably involved in cuticle biosynthesis are also expressed in roots (Krolikowski et al., 2003; Wellesen et al., 2001; Todd et al., 1999; Schnurr et al., 2004).

\subsection{The very long-chain fatty acid modification pathway}

Although the ubiquity in all higher plants suberin and cutin biosynthesis has not been elucidated in much detail and no enzyme directly involved in cutin and/or suberin biosynthesis has been characterized yet. Based on our compositional analysis we propose a hypothetical pathway (Fig. 7) for suberin and cutin biosynthesis in Arabidopsis, providing the basis for upcoming reverse genetic approaches. The precursors of this pathway are supplied by the pool of $\mathrm{C}_{16}$ and $\mathrm{C}_{18}$ carboxylic acids derived from plastidic fatty acid biosynthesis (Kunst et al., 2004; Bernards, 2002). The biosynthetic backbone is an $\omega$-oxidation pathway that functionalize the $\omega$-position of long-chain fatty acid derivatives. The $\omega$ hydroxylation reaction is typically catalyzed by oxygenand NADPH-dependent cytochrome P450 monooxygenases (Schuler and Werck-Reichhart, 2003), particularly of the Cyp86 and Cyp94 subfamilies (Duan and Schuler, 2005). Some of them have been demonstrated to catalyze the $\omega$ hydroxylation of fatty acids (Benveniste et al., 1998; Le Bouquin et al., 1999, 2001) but it is still a matter of debate whether any of these hydroxylases is involved in cutin and suberin biosynthesis or not. The $L C R$ gene, cloned from a putative cutin mutant with organ fusion phenotype, encoding a P450 (Cyp86A8) capable of the $\omega$-hydroxylation of $\mathrm{C}_{12}-\mathrm{C}_{18}$ fatty acids, has been proposed to be a candidate (Wellesen et al., 2001) as well as ATT1, encoding CYP86A2 and also cloned from a cutin mutant (Xiao et al., 2004). The HTH gene, isolated from another organ fusion mutant (Krolikowski et al., 2003), encoding a putative oxidoreductase might be involved in the subsequent formation of $\alpha, \omega-$ diacids catalyzed by a $\omega$-hydroxy fatty acid dehydrogenase and $\omega$-oxo fatty acid dehydrogenase (Agrawal and Kolattukudy, 1978). Recently, the tobacco P450 Cyp94A5 has been characterized to be able to catalyze the oxidation of $\omega$-hydroxy fatty acids to $\alpha, \omega$-diacids, indicating that this 


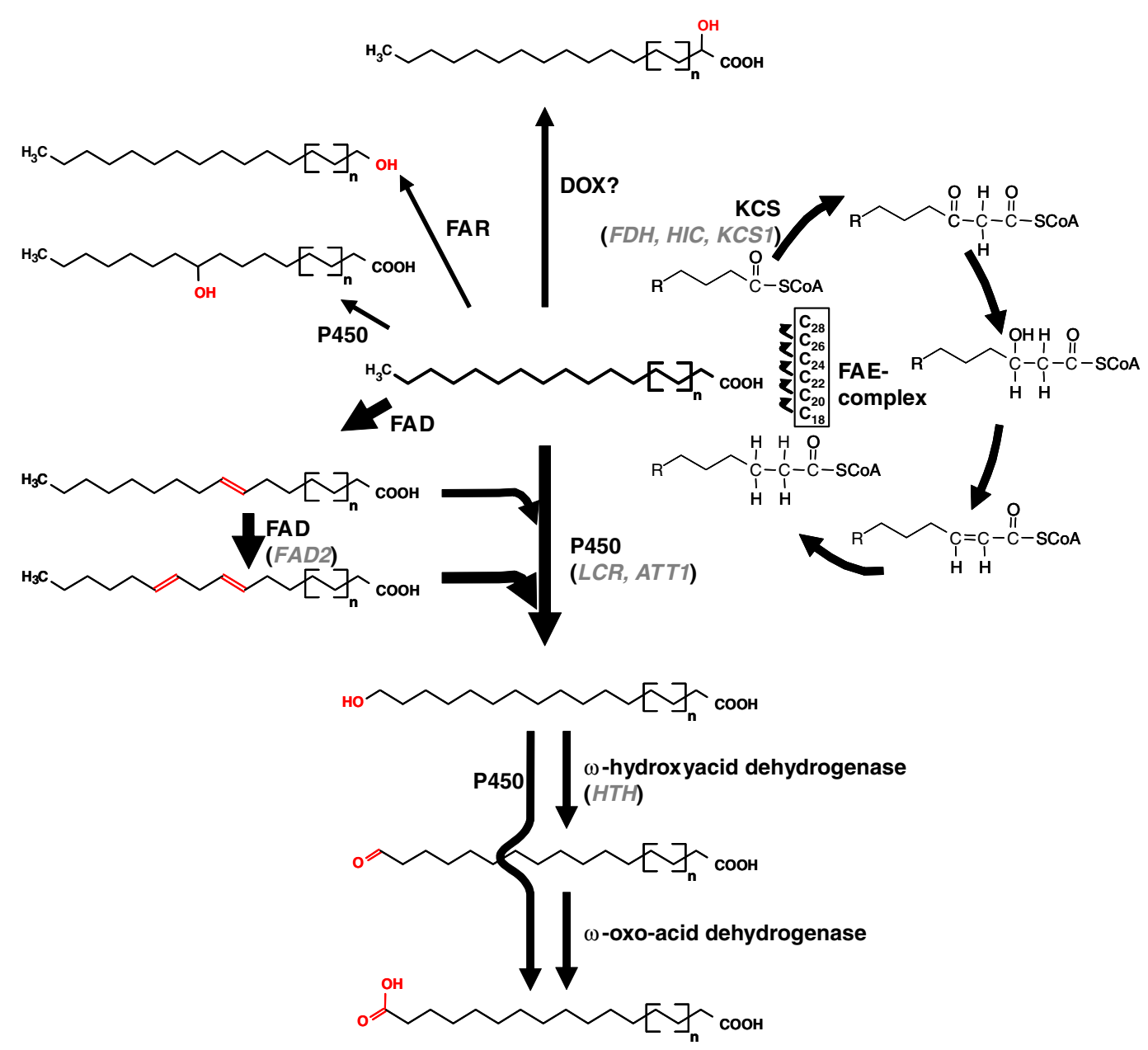

Fig. 7. Model of the biosynthetic pathways for cutin and suberin monomers in Arabidopsis. Enzymes presumably involved are indicated as follows: DOX, dioxygenase; FAD, fatty acid desaturase; FAE, fatty acid elongase; FAR, fatty acid reductase; KCS, $\beta$-ketoacyl-CoA-synthase; P450, Cytochrome P450 monooxygenase. Arabidopsis candidate genes are given in parenthesis as published. The various chain length is indicated by $n(n=1-7)$. Arrow thickness indicates the extend of carbon flux.

two-step reaction can also be catalyzed by a single enzyme (Le Bouquin et al., 2001). The mid-chain hydroxylation is another P450 catalyzed reaction that was demonstrated in Vicia faba leaf extracts (Kolattukudy, 1981) indicating that P450 are key enzymes in aliphatic suberin and cutin biosynthesis.

Based on the content of unsaturated $\mathrm{C}_{18}$ aliphatics, fatty acid desaturases (FAD) are involved in the biosynthesis of $30-35 \%$ of the cutin and suberin monomers. This was indicated by a decrease of double unsaturated $\mathrm{C}_{18} \alpha, \omega$-diacids in leaf polyester of the $f a d 2$ mutant (Bonaventure et al., 2004). Since in-chain modification seems not to be critical for the substrate specificity of the $\omega$-hydroxylase(s) (Benveniste et al., 1998), desaturated and mid-chain oxygenated fatty acids can enter the core $\omega$-oxidation pathway again. Alternatively, it has also been shown that both, desaturation and hydroxylation can be catalyzed by the same enzyme (Broadwater et al., 2002).

The production of 2-hydroxy acids is a totally unknown branch of this pathway. Dioxygenases that have been shown to catalyze a two step oxidation of unsaturated $\mathrm{C}_{16}$ and $\mathrm{C}_{18}$ fatty acids via hydroperoxides (Hamberg et al., 1999) have been proposed to be involved in the production of unsaturated 2-hydroxy fatty acids in plants. However, the process of $\alpha$-oxidation of saturated very long-chain fatty acids is not clear.

The long-chain carbon backbone of $\mathrm{C}_{20}-\mathrm{C}_{28}$ 2-hydroxy acids in the cutin and the $\mathrm{C}_{20}-\mathrm{C}_{24}$ monomers in suberin requires the elongation of the fatty acid precursors catalyzed by fatty acid elongase (FAE) complexes. $\beta$-ketoacyl-CoAsynthases (KCS) encoded by the so-called $F A E$ genes catalyze the rate-limiting step in the production of very long-chain fatty acid precursors (Millar and Kunst, 1997). The FAE genes $F D H$ and $H I C$ have been suggested to be involved in cuticle formation (Pruitt et al., 2000; Yephremov et al., 1999; Gray et al., 2000) and KCSI a root expressed FAE is involved in the biosynthesis of fatty acid precursors in roots (Todd et al., 1999) supporting the presumed pathway model.

\subsection{Future perspectives}

The methods for the quantitative and qualitative determination of cutin and suberin in Arabidopsis enable us to study the deposition of this protective polymers during normal 
plant development and in response to biotic and abiotic stress conditions and relate it to global gene expression studies to identify genes presumably involved in this processes. In addition, the array of identified mutants with altered leaf and root morphology, pathogen susceptibility or sensitivity to drought, humidity, herbicides and nutrient availability can now be subjected to biochemical phenotypic analysis. Finally, transgenic plants with altered cutin and/or suberin composition can be generated to study the physiological importance of cutin and suberin as an apoplastic barrier and to evaluate the biotechnological potential of cutin and suberin modification in agricultural important plants.

\section{Experimental}

\subsection{Plant material}

Arabidopsis thaliana L. Heynh. ecotype Columbia plants were cultivated in Floradur potting mix (Floraguard, Germany) at a light intensity of $100 \mu \mathrm{E} \mathrm{m}^{-2} \mathrm{~s}^{-1}$ at $22^{\circ} \mathrm{C}$ under a photoperiod of $16 \mathrm{~h}$ light $/ 8 \mathrm{~h}$ dark. 5-week-old fully developed flowering plants have been used for analysis.

\subsection{Cuticle isolation}

Cuticular membrane isolation was basically performed as described by Schönherr and Riederer (1986) with some modifications. Leaf disks of $1 \mathrm{~cm}$ diameter, intensively extracted with chloroform:methanol $(1: 1 ; \mathrm{v} / \mathrm{v})$ to remove soluble lipids and waxes, were used instead of native leaf disks. For the incubation with polysaccharide hydrolases $(1 \% \mathrm{v} / \mathrm{v}$ cellulase (Celluclast, Novo Nordisk, Denmark), $1 \% \mathrm{v} / \mathrm{v}$ pectinase (Trenolin, Erbslöh, Germany) in $10^{-2} \mathrm{M}$ citric buffer $\mathrm{pH} 3$, containing $10^{-3} \mathrm{M} \mathrm{NaN}_{3}$ ) leaf disks were not vacuum infiltrated to avoid damages. After 5-10 days with occasional agitation, leaf cuticles were collected with a micro spatula and transferred into $10^{-2} \mathrm{M}$ borate buffer $\mathrm{pH} 9$ to remove soluble lipophilic compounds possibly resorbed to the cuticle. After several days with renewal of the borate buffer, cuticles were finally washed with deionized water and 30 cuticles per sample were pooled and directly transferred into reaction vials for depolymerization.

\subsection{Totally extracted leaves}

20-50 rosette leaves were collected and scanned to determine the surface area using imaging software. The leaves were then exhaustively extracted with chloroform:methanol $(1: 1 ; \mathrm{v} / \mathrm{v})$ with daily change of solvent over a period of two weeks. After drying $30-50 \mathrm{mg}$ of extracted leaves were used for the depolymerization reaction.

\subsection{Isolation of suberized root cell wall material}

Roots were carefully dug out of the potting mixture and rinsed with tap water to remove all soil contaminants before they were finally washed with deionized water. 4-7 roots per sample were cut in $5 \mathrm{~mm}$ sections, transferred into the above enzyme solution containing polysaccharide hydrolases, vacuum infiltrated and incubated for 3 weeks with a weekly change of the enzyme solution. The remaining cell wall fraction was then washed using borate buffer $\left(10^{-2} \mathrm{M}, \mathrm{pH} 9\right)$ and water, and unbound lipids were removed by prolonged extraction in chloroform:methanol $(1: 1 ; \mathrm{v} / \mathrm{v}) .3-6 \mathrm{mg}$ of the cell wall material was used for depolymerization.

\subsection{Chemical degradation of polyesters}

Phytopolyesters can be depolymerized by any reagent used to cleave ester bounds. Acid catalyzed transesterification using borontrifluorid in methanol $\left(\mathrm{BF}_{3} / \mathrm{MeOH}\right)$, releasing solvent extractable methylesters suitable for GC and GC-MS analysis has often been used because it results in less background from other cell wall components and is more practicable compared to $\mathrm{KOH}$ or reduction with $\mathrm{LiAlH}_{4} / \mathrm{LiAlD}_{4}$ (Kolattukudy, 1980; Schreiber et al., 1999). As indicated by the disappearance of ester-associated absorbance bands, quantitative FT-IR-analysis has shown that $\mathrm{BF}_{3} / \mathrm{MeOH}$ quantitatively dissolves all aliphatic esters in suberized cell walls (Zeier and Schreiber, 1999; Schreiber et al., 2005a). Alternatively transmethylation with methanolic- $\mathrm{HCl}(\mathrm{MeOH} / \mathrm{HCl})$ can be used giving similar results (Holloway, 1982; Fig. S1).

\subsubsection{Suberin depolymerization}

The isolated root cell wall fraction was depolymerized by transesterification in a $10 \% \mathrm{BF}_{3} / \mathrm{MeOH}$ (Fluka) solution. To $3-6 \mathrm{mg}$ cell walls $1 \mathrm{ml} \mathrm{BF}_{3} / \mathrm{MeOH}$ was added and incubated in a teflon-sealed screw cap tube for $16 \mathrm{~h}$ at $70{ }^{\circ} \mathrm{C}$. The reaction was stopped by adding $2 \mathrm{ml}$ saturated $\mathrm{NaHCO}_{3} / \mathrm{H}_{2} \mathrm{O}$ to the methanolysate that was then extracted with chloroform (3 times) after $10 \mu \mathrm{g}$ of dotriacontane (Fluka) has been added as an internal standard. The combined organic phase was dried over $\mathrm{NaSO}_{4}$ and then evaporated in a stream of nitrogen. Free hydroxyl and carboxyl groups were converted into their trimethylsilyl (TMS) ethers and esters with bis-( $N, N$-trimethylsilyl)tri-fluoroacetamide (Machery-Nagel, Dueren, Germany) in pyridine for $40 \mathrm{~min}$ at $70^{\circ} \mathrm{C}$ prior to $\mathrm{GC}-\mathrm{MS}$ analysis.

\subsubsection{Cutin depolymerization}

Cutin monomers were solubilized by transesterification of 30 isolated cuticular membranes $(1 \mathrm{~cm}$ diameter $)$ or $30-50 \mathrm{mg}$ totally extracted leaves with $1 \mathrm{ml}$ or $6 \mathrm{ml} 1 \mathrm{~N}$ $\mathrm{MeOH} / \mathrm{HCl}$ (Supelco) for $2 \mathrm{~h}$ at $80^{\circ} \mathrm{C}$. After addition of $2 \mathrm{ml}$ saturated $\mathrm{NaCl} / \mathrm{H}_{2} \mathrm{O}$ the hydrophobic monomers were subsequently extracted in hexane (3 times) containing $20 \mu \mathrm{g}$ internal standard (Dotriacontane). The combined extracts were evaporated and derivatized as described above.

This method was chosen due to lower back ground levels in GC and GC-MS chromatographic analysis improving identification and quantification of low abundant 
compounds. Optimization studies comparing $\mathrm{MeOH} / \mathrm{HCl}$ transesterification to the above $\mathrm{BF}_{3} / \mathrm{MeOH}$ transesterification revealed no significant qualitative and quantitative differences. Furthermore, using enzymatically isolated Lycopersicon esculentum fruit cuticles, which are to $>80 \%$ comprised of 9(10),16-dihydroxy-hexadecanoic acid (Graça et al., 2002), we verified that on the applied scale hexane extraction of polyhydroxylated cutin depolymerization products is quantitative.

\section{6. $G C$ and GC-MS analysis of depolymerization products}

Monomers were identified from their EI-MS spectra $(70 \mathrm{eV}, \mathrm{m} / \mathrm{z} 50-700)$ after capillary GC (DB-1, $30 \mathrm{~m} \times$ $0.32 \mathrm{~mm}, 0.1 \mu \mathrm{m}(\mathrm{J} \& \mathrm{~W})$, on-column-injection at $50{ }^{\circ} \mathrm{C}$, oven $2 \mathrm{~min}$ at $50^{\circ} \mathrm{C}, 10^{\circ} \mathrm{C} \min ^{-1}$ to $150^{\circ} \mathrm{C}, 1 \mathrm{~min}$ at $150^{\circ} \mathrm{C}$, $3{ }^{\circ} \mathrm{C} \min ^{-1}$ to $310^{\circ} \mathrm{C}, 30 \mathrm{~min}$ at $310^{\circ} \mathrm{C}$ and $\mathrm{He}$ carrier gas with $2 \mathrm{ml} \mathrm{min}^{-1}$ ) on an Agilent $6890 \mathrm{~N}$ gas chromatograph combined with a quadrupole mass selective detector $5973 \mathrm{~N}$ (Agilent Technologies, Böblingen, Germany). Quantitative determination of cutin components was carried out with an identical GC-system equipped with a flame ionization detector based on the internal standard. The analyses were conducted with three (Table 1) or 10 (Table 2) replicates. Data are presented as means \pm standard deviation (SD).

\subsection{Light-microscopic techniques}

Whole root bundles, similar to the material used for suberin analysis, were washed and fixed in a mixture of glutaraldehyde $(1.75 \% ; \mathrm{v} / \mathrm{v})$ and formaldehyde $(2 \% ; \mathrm{v} / \mathrm{v})$ in phospate buffer saline $\left(10^{-2} \mathrm{M} \mathrm{NaPO}_{4}, 0.137 \mathrm{M} \mathrm{NaCl}\right.$, $27 \times 10^{-4} \mathrm{M} \mathrm{KCl}, \mathrm{pH} 7.4$ ) for $24 \mathrm{~h}$. The samples were frozen at $-50{ }^{\circ} \mathrm{C}$ and $20 \mu \mathrm{m}$ sections were cut using a cryo microtome (Cryostat H 500). Sections were transferred to microscope slides, embedded in glycerol:water $(1: 1 ; \mathrm{v} / \mathrm{v})$ and examined with an Axioplan microscope (Zeiss, Germany) with brightfield illumination or fluorescence excitation at $365 \mathrm{~nm}$ using filter LP397 (Zeiss). For Sudan staining according to Gerlach (1984) a saturated solution of Sudan III in $92 \%(\mathrm{v} / \mathrm{v})$ ethanol was applied to the sections and heated to $70^{\circ} \mathrm{C}$ for $30 \mathrm{~s}$, washed with water and examined after embedding in glycerol-water. Enzymatically isolated cuticular membranes were carefully transferred to glycerol-water and examined using the same microscope.

\subsection{Transmission electron microscopy of cell wall ultrastructure}

For the analysis of the cuticle ultra structure, rosette leaves of different age of 4- to 5-week-old plants, grown under a $12 \mathrm{~h} \mathrm{light/dark} \mathrm{cycle} \mathrm{were} \mathrm{investigated.} \mathrm{For} \mathrm{the}$ analysis of suberization of root tissues, the primary roots of 3-week-old agar-plate grown plants were analyzed as well as the oldest root parts of 8-week-old soil-grown plants. Small pieces of Arabidopsis leaves were fixed for
$2 \mathrm{~h}$ with $2 \%(\mathrm{v} / \mathrm{v})$ glutaraldehyde in $0.05 \mathrm{M}$ sodium cacodylate buffer ( $\mathrm{pH}$ 7.2) at room temperature. Small pieces of roots were fixed in paraformaldehyde $(2 \%)$ and glutaraldehyde $(1.5 \%)$ in $0.066 \mathrm{M}$ potassium phosphate buffer $(\mathrm{pH}$ 7.4) under the same conditions. Both materials were postfixed with $\mathrm{OsO}_{4}(1 \%)$ at $4{ }^{\circ} \mathrm{C}$ overnight in the corresponding buffers. After dehydration with aceton at room temperature, the material was embedded in Spurr's standard epoxy resin and the resin was polymerized at $70{ }^{\circ} \mathrm{C}$ for $18 \mathrm{~h}$. Thin sections were stained with $2 \%$ uranyl acetate (in $50 \%$ acetone) and alkaline lead citrate for $0.5 \mathrm{~h}$ each. Micrographs were taken with a Philips CM100BIOTWIN electron microscope (Philips Electron Optics, Eindhoven, The Netherlands). For measurements of cuticle thickness (mean $\pm \mathrm{SD}$ ) 14 independent samples were measured for leaf blade, 11 for veins and 6 for petioles.

\section{Acknowledgements}

We thank Ulrich Ryser for its collaboration for the TEM of suberin and cutin and Martine Schorderet for her excellent technical assistance. This work was supported by the Deutsche Forschungsgemeinschaft (D.F.G.)

\section{Appendix A. Supplementary data}

Supplementary data associated with this article can be found, in the online version, at doi:10.1016/ j.phytochem.2005.09.027.

\section{References}

Agrawal, V.P., Kolattukudy, P.E., 1978. Purification and characterization of a wound-induced $\omega$-hydroxy fatty acid:NADP oxidoreductase from potato tuber disks (Solanum tuberosum L.). Arch. Biochem. Biophys. $191,452-465$.

Agrios, G.N., 1997. Plant Pathology. Academic Press, San Diego.

Baker, E., Holloway, P., 1970. The constituent acids of angiosperm cutins. Phytochemistry 9, 1557-1562.

Benveniste, I., Tijet, N., Adas, F., Philipps, G., Salaun, J.P., Durst, F., 1998. CYP86A1 from Arabidopsis thaliana encodes a cytochrome P450-dependent fatty acid omega-hydroxylase. Biochem. Biophys. Res. Commun. 243, 688-693.

Bernards, M.A., 2002. Demystifying suberin. Can. J. Bot. 80, 227-240.

Bernards, M.A., Lewis, N.G., 1998. The macromolecular aromatic domain in suberized tissue: a changing paradigm. Phytochemistry 47, 915-933.

Bernards, M.A., Razem, F.A., 2001. The poly(phenolic) domain of potato suberin: a non-lignin cell wall bio-polymer. Phytochemistry 57, 1115 1122.

Bonaventure, G., Beisson, F., Ohlrogge, J., Pollard, M., 2004. Analysis of the aliphatic monomer composition of polyesters associated with Arabidopsis epidermis: occurrence of octadeca-cis-6, cis-9-diene-1,18dioate as the major component. Plant J. 40, 920-930.

Broadwater, J.A., Whittle, E., Shanklin, J., 2002. Desaturation and hydroxylation. J. Biol. Chem. 277, 15613-15620.

Chen, X., Goodwin, S.M., Boroff, V.L., Liu, X., Jenks, M.A., 2003. Cloning and characterization of the $W A X 2$ gene of Arabidopsis involved in cuticle membrane and wax production. Plant Cell 15, 1170-1185.

Deas, A., Holloway, P., 1977. The intermolecular structure of some plant cutins. In: Tevini, M., Lichtenthaler, H. (Eds.), Lipids and Lipid Polymers in Higher Plants. Springer, Berlin, pp. 293-299. 
Duan, H., Schuler, M.A., 2005. Differential expression and evolution of the Arabidopsis CYP86A subfamily. Plant Physiol. 137, 1067-1081.

Efremova, N., Schreiber, L., Bär, S., Heidmann, I., Huijser, P., Wellesen, K., Schwarz-Sommer, Z., Saedler, H., Yephremov, A., 2004. Functional conservation and maintenance of expression pattern of FIDDLEHEAD-like genes in Arabidopsis and Antirrhinum. Plant Mol. Biol. 56, 821-837.

Espelie, K.E., Kolattukudy, P.E., 1979. Composition of the aliphatic components of suberin of the endodermal fraction from the first internode of etiolated Sorghum seedlings. Plant Physiol. 63, 433-435.

Gerlach, D., 1984. Botanische Mikrotechnik. Thieme, Stuttgart.

Graça, J., Pereira, H., 2000a. Methanolysis of bark suberins: Analysis of glycerol and acid monomers. Phytochem. Anal. 11, 45-51.

Graça, J., Pereira, H., 2000b. Diglycerol alkenedioates in suberin: building units of a poly(acylglycerol) polyester. Biomacromolecules 1, 519-522.

Graça, J., Schreiber, L., Rodrigues, J., Pereira, H., 2002. Glycerol and glyceryl esters of omega-hydroxyacids in cutins. Phytochemistry 61 , 205-215.

Gray, J.E., Holroyd, G.H., van der Lee, F.M., Bahrami, A.R., Sijmons, P.C., Woodward, F.I., Schuch, W., Heterington, A.M., 2000. The HIC signalling pathway links $\mathrm{CO}_{2}$ perception to stomatal development. Nature 408, 713-716.

Hamberg, M., Sanz, A., Castresana, C., 1999. Alpha-oxidation of fatty acids in higher plants - Identification of a pathogen-inducible oxygenase (PIOX) as an alpha-dioxygenase and biosynthesis of 2hydroperoxylinolenic acid. J. Biol. Chem. 274, 24503-24513.

Heredia, A., 2003. Biophysical and biochemical characteristics of cutin, a plant barrier biopolymer. Biochim. Biophys. Acta 1620, 1-7.

Holloway, P.J., 1982. The chemical constitution of plant cutins. In: Cutler, D.F., Alvin, K.L., Price, C.E. (Eds.), The Plant Cuticle. Academic Press, London, pp. 45-85.

Hose, E., Schreiber, L., Clarskon, D., Steudle, E., Hartung, W., 2001. The exodermis: a variable apoplastic barrier in roots. J. Exp. Bot. 52, 2245 2264.

Jeffree, C.E., 1996. Structure and ontogeny of plant cuticles. In: Kerstiens, G. (Ed.), Plant Cuticles. BIOS Scientific Publishing Ltd., Oxford, pp. 33-82.

Kerstiens, G., 1996. Plant Cuticles: An Integrated Functional Approach. Bios Scientific Publishers Ltd., Oxford.

Kolattukudy, P.E., 1977. Biosynthesis and degradation of lipid polymers. In: Tevini, M., Lichtenthaler, H. (Eds.), Lipids and Lipid Polymers in Higher Plants. Springer, Berlin, pp. 271-292.

Kolattukudy, P.E., 1980. Biopolyesters of plants: cutin and suberin. Science 208, 990-1000

Kolattukudy, P.E., 1981. Structure, biosynthesis, and biodegradation of cutin and suberin. Ann. Rev. Plant. Physiol. 32, 539-567.

Kolattukudy, P.E., 2001a. Cutin from plants. In: Doi, Y., Steinbuechel, A. (Eds.), Biopolymers I - Biological Systems and Biotechnological Production, vol. 3. Wiley-VCH, Muenster, Germany, pp. 1-35.

Kolattukudy, P.E., 2001b. Suberin from plants. In: Doi, Y., Steinbuechel, A. (Eds.), Biopolymers I - Biological Systems and Biotechnological Production, vol. 3. Wiley-VCH, Muenster, Germany, pp. 41-68.

Krolikowski, K.A., Victor, J.L., Wagler, T.N., Lolle, S.J., Pruitt, R.E., 2003. Isolation and characterization of the Arabidopsis organ fusion gene HOTHEAD. Plant J. 35, 501-511.

Kunst, L., Samuels, A.L., 2003. Biosynthesis and secretion of plant cuticular wax. Prog. Lip. Res. 42, 51-80.

Kunst, L., Samuels, A.L., Jetter, R., 2004. The plant cuticle: formation and structure of epidermal surfaces. In: Murphy, D.J. (Ed.), Plant Lipids - Biology, Utilisation and Manipulation. Blackwell Publishing, Oxford, pp. 270-302.

Kurata, T., Kawabata-Awai, C., Sakuradani, E., Shimizu, S., Okada, K., Wada, T., 2003. The YORE-YORE gene regulates multiple aspects of epidermal cell differentiation in Arabidopsis. Plant J. 36, 55-66.

Le Bouquin, R., Pinot, F., Benveniste, I., Salaün, J.-P., Durst, F., 1999. Cloning and functional characterization of CYP94A2, a medium chain fatty acid hydroxylase from Vicia sativa. Biochem. Biophys. Res. Commun. 261, 156-162.
Le Bouquin, R., Skrabs, M., Kahn, R., Benveniste, I., Salaün, J.P., Schreiber, L., Durst, F., Pinot, F., 2001. Cyp94A5, a new cytochrome P450 from Nicotiana tabacum is able to catalyze the oxidation of fatty acids to the omega-alcohol and to the corresponding diacid. Eur. J. Biochem. 268, 3083-3090.

Lynch, D.V., Dunn, T.M., 2004. An introduction to plant sphingolipids and a review of recent advances in understanding their metabolism and function. New Phytol. 161, 677-702.

Matzke, K., Riederer, M., 1990. The composition of the cutin of the caryopses and leaves of Triticum aestivum L.. Planta 182, 461-466.

Matzke, K., Riederer, M., 1991. A comparative study into the chemical constitution of cutins and suberins from Picea abies (L.), Karst., Quercus robur L., and Fagus sylvatica L.. Planta 185, 233-245.

Millar, A.A., Kunst, L., 1997. Very-long chain fatty acid biosynthesis is controlled through the expression and specificity of the condensing enzyme. Plant J. 12, 121-131.

Nawrath, C., 2002. The biopolymers cutin and suberin. In: Somerville, C.R., Meyerowitz, E.M. (Eds.), The Arabidopsis Book. American Society of Plant Biologists, Rockville, MD. doi:10.1199/ tab.0021. Available from: <http://www.aspb.org/publications/ arabidopsis/>.

Pruitt, R.E., Vielle-Calzada, J.P., Ploense, S.E., Grossniklaus, U., Lolle, S.J., 2000. FIDDLEHEAD, a gene required to suppress epidermal cell interactions in Arabidopsis, encodes a putative lipid biosynthetic enzyme. Proc. Nat. Acad. Sci. USA 97, 1311-1316.

Schaeffer, A., Bronner, R., Benveniste, P., Schaller, H., 2001. The ratio of campesterol to sitosterol that modulates growth in Arabidopsis is controlled by sterol methyltransferase. Plant J. 25, 605-615.

Schmutz, A., Buchala, A.J., Ryser, U., 1996. Changing the dimensions of suberin lamellae of green cotton fibers with a specific inhibitor of the endoplasmic reticulum-associated fatty acid elongases. Plant Physiol. $110,403-411$.

Schnurr, J., Shockey, J., Browse, J., 2004. The acyl-CoA synthetase encoded by LACS2 is essential for normal cuticle development in Arabidopsis. Plant Cell 16, 629-642.

Schönherr, J., Riederer, M., 1986. Plant cuticles sorb lipophilic compounds during enzymatic isolation. Plant Cell Environ. 4, 349-354.

Schreiber, L., Schönherr, J., 1990. Phase transitions and thermal expansion coefficients of plant cuticles. The effects of temperature on structure and function. Planta 182, 186-193.

Schreiber, L., Riederer, M., 1996. Ecophysiology of cuticular transpiration: comparative investigation of cuticular water permeability of plant species from different habitats. Oecologia 107, 426-432.

Schreiber, L., Hartmann, K., Skrabs, M., Zeier, J., 1999. Apoplastic barriers in roots: chemical composition of endodermal and hypodermal cell walls. J. Exp. Bot. 50, 1267-1280.

Schreiber, L., Franke, R., Hartmann, K., 2005a. Wax and suberin development of native and wound periderm of potato (Solanum tuberosum L.) and its relation to peridermal transpiration. Planta 220, $520-530$.

Schreiber, L., Franke, R., Hartmann, K., Ranathunge, K., Steudle, E., 2005b. The chemical composition of suberin in apoplastic barriers affects radial hydraulic conductivity differently in the roots of rice (Oryza sativa L. cv. IR64) and corn (Zea mays L. cv. Helix). J. Exp. Bot. 56, 1427-1436.

Schuler, M.A., Werck-Reichhart, D., 2003. Functional genomics of P450s. Ann. Rev. Plant Biol. 54, 629-667.

Todd, J., Post-Beittenmiller, D., Jaworski, J.G., 1999. KCS1 encodes a fatty acid elongase 3-ketoacyl-CoA synthase affecting wax biosynthesis in Arabidopsis thaliana. Plant J. 17, 119-130.

Villena, J.F., Dominguez, E., Stewart, D., Heredia, A., 1999. Characterization and biosynthesis of non-degradable polymers in plant cuticles. Planta 208, 181-187.

Vogg, G., Fischer, S., Leide, J., Emmanuel, E., Jetter, R., Levy, A.A., Riederer, M., 2004. Tomato fruit cuticular waxes and their effects on transpiration barrier properties: functional characterization of a mutant deficient in a very-long-chain fatty acid beta-ketoacyl-CoA synthase. J. Exp. Bot. 55, 1401-1410. 
Wellesen, K., Durst, F., Pinot, F., Benveniste, I., Nettesheim, K., Wisman, E., Steiner-Lange, S., Saedler, H., Yephremov, A., 2001. Functional analysis of the LACERATA gene of Arabidopsis provides evidence for different roles of fatty acid $\omega$-hydroxylation in development. Proc. Nat. Acad. Sci. USA 98, 9694-9699.

Wilson, C.A., Peterson, C.A., 1983. Chemical composition of the epidermal, hypodermal, endodermal and intervening cortical cell walls of various plant roots. Ann. Bot. 51, 759-769.

Xiao, F., Goodwin, M.S., Xiao, Y., Sun, Z., Baker, D., Tang, X., Jenks, M.A., Zhou, J.M., 2004. Arabidopsis CYP86A2 represses Pseudomonas syringae type III genes and is required for cuticle development. EMBO J. 23, 2903-2913.

Yephremov, A., Schreiber, L., 2005. The dark side of the cell wall: molecular genetics of the plant cuticle. Plant Biosyst. 139, 7479.

Yephremov, A., Wisman, E., Huijser, P., Huijser, C., Wellesen, K., Saedler, H., 1999. Characterization of the FIDDLEHEAD gene of Arabidopsis reveals a link between adhesion response and cell differentiation in the epidermis. Plant Cell 11, 21872201.
Yephremov, A., Faust, A., Kurdyukov, S., Trenkamp, S., Nawrath, C., Franke, R., Wojciechowski, T., Efremova, N., Voisin, D., Toro, F., Tietjen, K., Schreiber, L., Saedler, H., 2004. Safeguarding the cuticular wall. In: Proceedings of the Xth Cell Wall Meeting, Sorrento, 29.8.2004-3.9.2004, Italy, p. 99.

Zeier, J., Schreiber, L., 1998. Comparative investigation of primary and tertiary endodermal cell walls isolated from the roots of five monocotyledoneous species: chemical composition in relation to fine structure. Planta 206, 349-361.

Zeier, J., Schreiber, L., 1999. Fourier transform infrared-spectroscopic characterisation of isolated endodermal cell walls from plant roots: chemical nature in relation to anatomical development. Planta 209, 537-542.

Zeier, J., Goll, A., Yokoyama, M., Karahara, I., Schreiber, L., 1999a. Structure and chemical composition of endodermal and rhizodermal hypodermal walls of several species. Plant Cell Environ. 22, 271-279.

Zeier, J., Ruel, K., Ryser, U., Schreiber, L., 1999b. Chemical analysis and immunolocalisation of lignin and suberin in endodermal and hypodermal/rhizodermal cell walls of developing maize (Zea mays L.) primary roots. Planta 209, 1-12. 